\title{
Concentrations of lead and other elements in the liver of the white-tailed eagle (Haliaeetus albicilla), a European flagship species, wintering in Eastern Poland
}

\author{
Ignacy Kitowski, Dariusz Jakubas, Dariusz Wiącek, Agnieszka Sujak
}

Received: 1 December 2016/Revised: 7 April 2017/Accepted: 5 June 2017/Published online: 15 June 2017

\begin{abstract}
As a top predator, the white-tailed eagle (Haliaeetus albicilla) may serve as a good indicator species, providing information about the bioavailability of contaminants and their transfer within the food chain. In this study, we aimed to determine the common sources of origin of 17 metals and other elements in the liver of whitetailed eagles, and to compare the variations in their hepatic concentrations by age (adults vs immatures) and sex (males vs females) in groups of white-tailed eagles wintering in Eastern Poland. The element concentrations followed the pattern of $\mathrm{S}>\mathrm{K}>\mathrm{Na}>\mathrm{Fe}>\mathrm{Mg}>\mathrm{Ca}>\mathrm{Zn}>\mathrm{Cu}>\mathrm{Mn}>$ $\mathrm{Se}>\mathrm{Pb}>\mathrm{Hg}>\mathrm{Cd}>\mathrm{Cr}>\mathrm{Sr}>\mathrm{V}>$ Sc. We found significant age-related differences in the hepatic concentrations of some of the elements. Adults showed higher concentrations of $\mathrm{Pb}, \mathrm{Cd}, \mathrm{Ca}, \mathrm{Fe}$, and $\mathrm{Zn}$ and lower concentrations of $\mathrm{Cu}$ and $\mathrm{Se}$ than immatures. These differences may be explained by age-related differences in wintering strategy (adults are sedentary, and immatures are migratory) and hunting skills (adults are more successful when hunting for agile prey). Our study indicates that ingested $\mathrm{Pb}$ ammunition poses a serious threat to the health and lives of white-tailed eagles in Poland (32\% of the studied individuals had acute lead poisoning). Our study also indicates a serious need for banning the use of lead hunting ammunition in the parts of Europe (including Poland) where it is still allowed.
\end{abstract}

Keywords Bioaccumulation · Lead ammunition ·

Liver · Raptors · Trace elements

\section{INTRODUCTION}

As biomonitoring sentinels, raptors can provide early warnings of the potential impacts of contaminants on humans and the environment and can act as a means of tracking the success of associated mitigation measures (Kim et al. 2008; Ansara-Ross et al. 2013; Gomez-Ramírez et al. 2014). The value of birds as biomonitors of environmental pollution has been widely recognized (Horai et al. 2007; Schummer et al. 2011; Kim and Oh 2015). Owing to their top position in food webs, relatively long lifespan over which contaminants are accumulated, and exposure over different temporal and spatial scales (Jager et al. 1996; Castro et al. 2011; Kim and Oh 2015), birds of prey are considered to be good avian sentinels of environmental contamination. Their response to chemicals ranges from residue accumulation to population decline (Gomez-Ramírez et al. 2014).

Livers are frequently used for bioindication purposes (Horai et al. 2007; Castro et al. 2011; Schummer et al. 2011; Kalisinska et al. 2014a). On the one hand, this organ serves as a reservoir of many vital substances; on the other hand, it plays an important role in the detoxification of accumulated toxic material (e.g., toxic heavy metals). Research indicates that proteins rich in sulfur amino acids play an important role in detoxification. Detoxification processes are determined by the proper intake of sulfur (in the form of sulfur amino acids) (Tamas and Martinoia 2006; Nimni et al. 2007; Toohey 2014).

The white-tailed eagle, Haliaeetus albicilla, has been especially promoted as a sentinel species for various environmental contaminants. It is a long-lived top predator with a wide home range. This species may perform partial migration (Cramp and Simmons 1980; Nadjafzadeh et al. 2016a). As eagles are often considered umbrella, flagship, and keystone species, they are of high conservation priority, and their health state (i.e., contamination level) is important to assess the population condition. Currently, the white-tailed eagle population in Europe is undergoing a 
considerable increase and territorial expansion due to the cessation of persecution and the massive use of pesticides (especially DDT), as well as the effective protection of nesting sites (Deinet et al. 2013). In Poland, this species is widely distributed. Its population is estimated to be 1400-1500 breeding pairs (Chodkiewicz et al. 2013, 2015), making up $11 \%$ of European population and constituting the largest European mainland breeding population (Deinet et al. 2013). However, the Polish population is less genetically diverse than populations in other Central and East European countries. This lower diversification may have resulted from a bottleneck in the twentieth century (Hailer et al. 2007; Langguth et al. 2013). The white-tailed eagle is associated with aquatic habitats. It breeds in Central and Eastern Europe in coastal areas and wide river valleys that are rich in lakes and fish ponds (Cramp and Simmons 1980; Nadjafzadeh et al. 2016a). Females (4-6 kg) are slightly heavier and larger than males (3.5-4.5 kg) (Cramp and Simmons 1980; Mizera 2004), and a breeding pair occupies a hunting territory of $100 \mathrm{~km}^{2}$. The diet of the white-tailed eagle mainly consists of fish and waterbirds (Cramp and Simmons 1980; Mizera 2004; Nadjafzadeh et al. 2016a). It hunts for $0.100-8.0-\mathrm{kg}$ fish, preferring a $0.5-3.0 \mathrm{~kg}$ range. In Poland, the species mainly preys on crucian carp, Carassius carassius (at fish farms); bream, Abramis brama; northern pike, Esox lucius; and roach, Rutilus rutilus (in lakes) (Zawadzka 1999, Zawadzka et al. 2006). Coots, Fulica atra, and mallards, Anas platyrhynchos, are the most common avian prey (Zawadzka 1999; Zawadzka et al. 2006), and European white-tailed eagles, especially immature individuals in winter, regularly forage on carrion (Zawadzka 1999; Mizera 2004; Zawadzka et al. 2006). In Central Europe, including Poland, adults are sedentary and winter in their territories, while immatures migrate up to a few hundred km. (Cramp and Simmons 1980; Mizera 2004; Nadjafzadeh et al. 2016a).

The aims of this study were to (1) determine the hepatic concentrations of metals and elements in 22 white-tailed eagles from Eastern Poland, (2) compare the variations in the hepatic concentrations of 17 elements by age (adults, immatures) and sex (males, females), and (3) compare the concentrations of elements between birds collected in two regions (southern and northern) of Eastern Poland that differ in their habitat composition (Table 1).

Based on the diet composition of the study species, we expect the main sources of trace element assimilation to be as follows: hunting ammunition $(\mathrm{Pb})$, fertilizers $(\mathrm{Cd}, \mathrm{Cr}$, and $\mathrm{V})$, and aquatic prey $(\mathrm{Cu}, \mathrm{Mn}$, and $\mathrm{Hg})$. It must be emphasized that $\mathrm{Hg}, \mathrm{Cd}$, and $\mathrm{Pb}$ are extremely toxic elements. Considering the age-related differences in hunting effectiveness, we expect that immature eagles may hunt in suboptimal areas and focus on suboptimal prey (e.g., carrion) and thus be more prone to $\mathrm{Pb}$ contamination than experienced adults. Because sexual dimorphism in raptors affects prey selection (Krüger 2005; Slagsvold and Sonerud 2007), we expect there to be differences between males and females in their exposure to contamination. As white-tailed eagles may exploit prey and carrion contaminated with lead from hunting ammunition (Helander et al. 2009; Nadjafzadeh et al. 2013), we expect elevated lead concentrations, at least in some individuals, which may be associated with the elevated accumulation of other elements. Considering the differences in habitat composition of the regions from which the birds were collected, we may expect higher $\mathrm{Pb}$ accumulation in lake lands, where whitetailed eagles may hunt for ducks shot by lead ammunition.

\section{MATERIALS AND METHODS}

\section{Origin of the studied birds}

Livers were collected and analyzed from 22 dead whitetailed eagles that had been delivered as wounded to veterinary clinics in Eastern Poland (Fig. 1) in winter (December-March) from 2009 to 2014. The birds either died or, because they were untreatable upon delivery, were euthanized by lethal injection by veterinary doctors to spare them from suffering; the total stay of the raptors in the clinics or rehabilitation centers did not exceed 7 days. The birds were sexed by internal examination after dissection and classified as being immature (less than 2 years old) or adult (over 2 years old) on the basis of plumage, gonad development, and iris color (Helander et al. 1989, 2009; Forsman 1999). Data provided on a wet weight

Table 1 Relative area $(\%)$ of particular habitats in 20-km buffers around the sampling sites [according to the CORINE Land Cover model (CLC2012)] in the northern $(\mathrm{N}, N=13)$ and southern $(\mathrm{S}, N=7)$ regions of the study area

\begin{tabular}{lcccccc}
\hline Region & Arable land & Pastures & Artificial surfaces & Forests & Water bodies & Wetlands \\
\hline $\mathrm{N}$ & 38.5 & 7.1 & 2.4 & 36.6 & 7.3 & 0.8 \\
$\mathrm{~S}$ & 40.6 & 9.6 & 3.4 & 34.0 & 7.2 & 0.8 \\
$\chi^{2}$ test & 4.42 & 37.69 & 15.32 & 0.007 & 353.62 & $<0.0001$ \\
$P$ & 0.03 & $<0.0001$ & 0.0001 & & & 0.01 \\
\hline
\end{tabular}




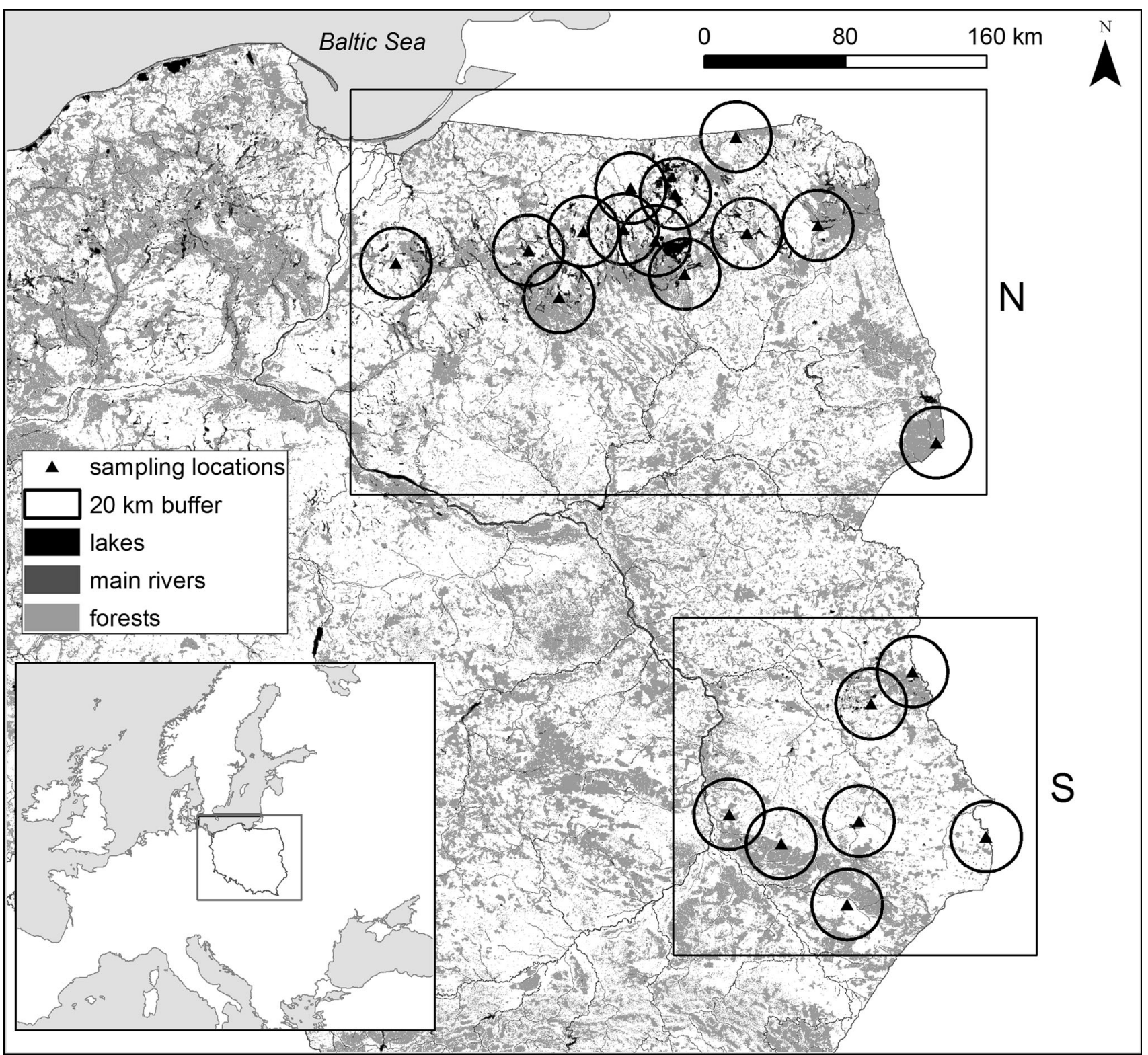

Fig. 1 Study area in Eastern Poland divided into northern $(\mathrm{N})$ and southern $(\mathrm{S})$ parts with the locations of sampling sites with 20-km buffers. Two locations are not shown and were not considered for analysis because only two eagles were found in each

(ww) basis were converted to dry weight (dw) using a factor of 0.75, following Kalisińska et al. (2006).

The study area was divided into two sections: the northern region (14 sample sites), which is characterized by a high number of lakes, and the southern region (6 sample sites), which is characterized by a farmland landscape with a smaller number of water bodies. The northern region consists of two subprovinces [according to the physicogeographical regionalization of Poland (Kondracki 2002)]: the Eastern Baltic Lakelands (Pojezierze Wschodniobałtyckie) and the Podlasie-Byelorussian Upland (Wysoczyzny Podlasko-Białoruskie). The first subprovince is characterized by a postglacial landscape with a high number and area of lakes (this subprovince includes the Masurian Lakeland) and forests. The second subprovince in the northern region is an upland area with a small number of lakes but a considerable number of river valleys and inland marshes. The southern region mainly includes two subprovinces: Polesie and the Lublin-Lviv Upland. The first subprovince is a flat area with shallow and wide inland marshes and moraine plains, and it is mainly covered by agricultural areas and forests. The second subprovince is an upland area with river valleys, and is one of the most-developed agricultural regions in Poland. In the 
northern region, water bodies and forests covered a greater relative area in $20-\mathrm{km}$ buffers around the sampling sites (see details about buffers in "Statistical analyses") compared with the southern region. By contrast, the relative areas of arable land, artificial cover, and pastures around the sampling sites in the southern region were larger than in the northern region (Table 1).

\section{Laboratory analyses}

Livers were extracted from the corpses of the birds with a ceramic knife and stored in polyethylene bags in the freezer at $-30{ }^{\circ} \mathrm{C}$ prior to the analyses. The samples were then lyophilized and ground in a ceramic mortar. Experimental methods were followed with modifications to those previously published (Kitowski et al. 2014). All glassware and utensils were rinsed with tap water, soaked in an acid bath $\left(5 \mathrm{M} \mathrm{HNO}_{3}\right.$ ) for $24 \mathrm{~h}$, rinsed with demineralized water and dried under a laminar flow hood before use to minimize the risk of any metal contamination. Weighted portions of the samples $(500 \pm 1 \mathrm{mg})$ with $10 \mathrm{~mL}$ of concentrated $\mathrm{HNO}_{3}$ (Sigma Aldrich) were subjected to wet-ashing, and mineralization was carried out using a microwave digestion system with optical temperature and pressure monitoring of each individual sample during acid digestion (Berghof Speedwave) in Teflon vials (DAP 100 type). The mineralization process ran as follows: $15 \mathrm{~min}$ from room temperature to $140{ }^{\circ} \mathrm{C}, 5 \mathrm{~min}$ at $140{ }^{\circ} \mathrm{C}, 5 \mathrm{~min}$ from 140 to $170{ }^{\circ} \mathrm{C}$, $15 \mathrm{~min}$ at $170{ }^{\circ} \mathrm{C}$, and cooling to room temperature (variable time); the pressure over the entire mineralization process did not exceed 12 bar. After completing the mineralization process, a clear solution of elements was obtained, which was cooled to room temperature, transferred to a $50-\mathrm{mL}$ volumetric flask and filled with demineralized water (ELGA Pure Lab Classic) to the indicated level. Inductively coupled plasma optical emission spectrometry (ICP-OES) with a Thermo Scientific iCAP Series 6500 analyzer equipped with a charge injection device (CID) was used for the identification of elements. The spectrometer was controlled by PCbased iTEVA software, and the following instrumental settings were used: RF generator power of $1150 \mathrm{~W}, \mathrm{RF}$ generator frequency of $27.12 \mathrm{MHz}$, coolant gas flow rate of $16 \mathrm{~L} \mathrm{~min}^{-1}$, carrier gas flow rate of $0.65 \mathrm{~L} \mathrm{~min}^{-1}$, auxiliary gas flow rate of $0.4 \mathrm{~L} \mathrm{~min}^{-1}$, max integration time of $15 \mathrm{~s}$, pump rate of $50 \mathrm{rpm}$, axial viewing configuration, 3 replicates, and a 20-s flush time. We used the following multielement stock solutions (Inorganic Ventures) as standards:

(A) Analityk $46{ }^{63} \mathrm{Cu},{ }^{57} \mathrm{Fe},{ }^{24} \mathrm{Mg},{ }^{31} \mathrm{P},{ }^{39} \mathrm{~K}$, and ${ }^{23} \mathrm{Na}$ in $1000 \mathrm{mg} \mathrm{L}^{-1}$ of $5 \% \mathrm{HNO}_{3}$;

(B) Analityk $47{ }^{27} \mathrm{Al},{ }^{75} \mathrm{As},{ }^{111} \mathrm{Cd},{ }^{52} \mathrm{Cr},{ }^{208} \mathrm{~Pb},{ }^{55} \mathrm{Mn}$, ${ }^{201} \mathrm{Hg},{ }^{60} \mathrm{Ni},{ }^{45} \mathrm{Sc},{ }^{79} \mathrm{Se},{ }^{88} \mathrm{Sr},{ }^{51} \mathrm{~V}$, and ${ }^{66} \mathrm{Zn}$ in $100 \mathrm{mg} \mathrm{L}^{-1}$ of $10 \% \mathrm{HNO}_{3}$;
(C) Analityk $83{ }^{63} \mathrm{Cu},{ }^{39} \mathrm{~K},{ }^{24} \mathrm{Mg},{ }^{23} \mathrm{Na},{ }^{31} \mathrm{P}$, and ${ }^{32} \mathrm{~S}$ in $1000 \mathrm{mg} \mathrm{L}^{-1}$ of $5 \% \mathrm{HNO}_{3}$.

Samples (eagle livers) were run simultaneously with a blank (control) sample, and each liver sample was divided into two subsamples and analyzed in duplicate. A certified reference material, TraceCERT periodic table mix 1 for ICP (Fluka Analytical, Sigma Aldrich), was used to control the accuracy of the method under the existing working conditions, and three randomly selected samples were supplied with known amounts of the analytical standard to calculate the recovery percentage. Concentrations of all the examined elements were used as positive controls (Table 2), and the mean recovery percentages of the analyzed elements were calculated according to the following equation:

Recovery $[\%]=(\mathrm{CE} / \mathrm{CS} \times 100)$,

where $\mathrm{CE}$ was the experimental concentration determined from the calibration curve, and CS was the spiked concentration.

All the obtained concentrations were presented as $\mathrm{mg} \mathrm{kg}^{-1} \mathrm{dw}$. To compare the results with data from other authors presented in wet weight, a conversion factor of 4.0 was used because the water content of the liver is estimated to be $75 \%$ (Kalisińska et al. 2006). Liver Cd levels $\geq 3 \mathrm{mg} \mathrm{kg}^{-1} \mathrm{dw}$ were classified as indicative of increased environmental exposure (Burgat 1990; Battaglia et al. 2005). Shore et al. (2011) proposed hepatic $\mathrm{Hg}$

Table 2 Validation of the analytical method used in this study: linearity (the ability of the method to obtain test results proportional to the concentration of the analyte), limit of detection (LOD), and recoveries for the studied elements

\begin{tabular}{lllc}
\hline Element & Linearity correlation $r$ & LOD $\left(\mathrm{mg} \mathrm{L}^{-1}\right)$ & Recovery (\%) \\
\hline $\mathrm{Ca}$ & 0.9986 & 0.002 & 107 \\
$\mathrm{Cd}$ & 0.9999 & 0.001 & 98 \\
$\mathrm{Cr}$ & 0.9998 & 0.002 & 97 \\
$\mathrm{Cu}$ & 0.9999 & 0.002 & 103 \\
$\mathrm{Fe}$ & 0.9999 & 0.012 & 111 \\
$\mathrm{Hg}$ & 0.9997 & 0.052 & 93 \\
$\mathrm{~K}$ & 0.9995 & 0.120 & 105 \\
$\mathrm{Mg}$ & 0.9982 & 0.005 & 109 \\
$\mathrm{Mn}$ & 0.9998 & 0.002 & 96 \\
$\mathrm{Na}$ & 0.9982 & 0.005 & 103 \\
$\mathrm{~Pb}$ & 0.9999 & 0.008 & 97 \\
$\mathrm{~S}$ & 0.9985 & 0.004 & 106 \\
$\mathrm{Sc}$ & 0.9998 & 0.002 & 99 \\
$\mathrm{Se}$ & 0.9999 & 0.011 & 94 \\
$\mathrm{Sr}$ & 0.9998 & 0.003 & 97 \\
$\mathrm{~V}$ & 0.9999 & 0.003 & 95 \\
$\mathrm{Zn}$ & 0.9998 & 0.010 & 103 \\
\hline
\end{tabular}


concentrations $>6.7 \mathrm{mg} \mathrm{kg}^{-1} \mathrm{dw}$ to be associated with adverse effects on avian reproduction, and $\mathrm{Hg}$ values $>67.0 \mathrm{mg} \mathrm{kg}^{-1} \mathrm{dw}$ may result in death for non-marine birds. Hepatic concentrations of $\mathrm{Pb} \geq 6 \mathrm{mg} \mathrm{kg}^{-1} \mathrm{dw}$ were considered diagnostic of elevated exposure to $\mathrm{Pb}$ resulting in subclinical toxicity (Pain et al. 1995; Helander et al. 2009), while $\geq 15 \mathrm{mg} \mathrm{kg}^{-1} \mathrm{dw}$ is considered diagnostic of $\mathrm{Pb}$ poisoning (Franson 1996); acute $\mathrm{Pb}$ poisoning has been observed to occur when liver concentrations exceed $30 \mathrm{mg} \mathrm{kg}^{-1}$ (Martin et al. 2008). These thresholds are based on published data that relate hepatic $\mathrm{Pb}$ concentrations in raptors to evidence $\mathrm{Pb}$ poisoning, as well as subclinical effects (Pain et al. 1995; Franson 1996; Martin et al. 2008). Selenium at the level of $4-10 \mathrm{mg} \mathrm{kg}^{-1} \mathrm{dw}$ is considered the background concentration in avian liver tissue (Ohlendorf 1989). In this study, a hepatic Se concentration $>10 \mathrm{mg} \mathrm{kg}^{-1} \mathrm{dw}$ was taken as exceeding the background level. In the case of zinc, $200 \mathrm{mg} \mathrm{kg}^{-1} \mathrm{dw}$ was considered the background concentration in liver tissue (Honda et al. 1990). The $\mathrm{Hg} / \mathrm{Se}$ molar ratio was calculated based on the molar weights of the above elements: $78.96 \mathrm{~g} \mathrm{~mol}^{-1} \mathrm{Se}$ and $200.59 \mathrm{~g} \mathrm{~mol}^{-1} \mathrm{Hg}$.

\section{Statistical analyses}

To identify element concentration patterns, i.e., to find groups of elements with high degrees of association/correlation, we performed the following analyses:

(1) Spearman rank correlation;

(2) Principal component analysis (PCA) to reduce the number of variables and to assign new ones as factors representing groups of elements with significantly correlated concentrations; this analysis was performed on log-transformed data.

Intergroup differences in element concentrations were investigated using two methods:

(1) Multivariate (for all elements together) PERMANOVA (non-parametric MANOVA based on the Bray-Curtis measure; Anderson 2001) with fixed factors (age and sex) and their interaction as explanatory variables;

(2) The similarity percentage breakdown (SIMPER) procedure to assess the average percentage contribution of individual factors to the dissimilarity between objects in a Bray-Curtis dissimilarity matrix (Clarke 1993);

(3) Univariate analysis (for particular elements) using ANOVA and then a post hoc HSD test for unequal N (Sokal and Rohlf 1981) for normal data and
PERMANOVA for non-normal data (Anderson 2001).

Separate Spearman correlations were performed to investigate whether the size of the area of a particular habitat near where the studied white-tailed eagles were found (sample site) is related to the hepatic concentrations of particular elements. First, the areas of the six most important habitats, arable land, pastures, artificial surfaces (including urbanized and industrial areas), forests, water bodies, and wetlands, in $20-\mathrm{km}$ buffers around where white-tailed eagles were found and delivered to veterinary clinics were calculated based on the CORINE Land Cover model (CLC2012) (European Environment Agency 2012). However, it should be noted that the distance traveled by some individual white-tailed eagles from the center of the home range can be greater (Nadjafzadeh et al. 2016b).

Because the CLC2012 model is restricted to the European Union, it was not possible to obtain complete data for 4 locations on the border with Belarus and Ukraine; assuming 20-km buffers for the Białowieża, Gołdap, Kryłów, and Włodawa sample sites, it was only possible to obtain data for $49,63,54$, and $65 \%$ of the landscape surface, respectively. Thus, to enable comparisons with locations with full landscape data coverage, the relative area (percentage) of each habitat in the Polish part of the $20-\mathrm{km}$ buffer was used in all calculations (i.e., the areas were proportionally smaller in the case of the border locations). Spatial analyses (the extraction of particular landscape features and the area calculations) were performed using ArcMap software, version 10.3.1 (ArcGIS, ESRI, Redlands, California, USA). To compare the proportions of the habitat areas between the northern and southern regions, $2 \times 2 \chi^{2}$ tests were performed, and to compare the element concentrations in birds from the northern and southern regions, a Mann-Whitney $U$ test was applied. A total of 20 sites were analyzed; only two eagles were collected in each of two additional sites.

A $Q-Q$ plot (the quantile expected from a normal distribution vs the observed quantile plot for residuals), as well as Levene's test were used to assess whether the data met the assumptions of the linear model. Data for $\mathrm{Ca}, \mathrm{Hg}$, $\mathrm{Zn}$ were normalized using Box-Cox transformations, and the data for Fe were analyzed by PERMANOVA. Correlation strength was determined following Hinkle et al. (2003) as a strong correlation $(r=10.90-1.001)$, a high correlation $(r=10.70-0.90 \mid)$, or a moderate correlation $(r=10.50-0.70 \mathrm{l})$. Statistical analyses were conducted in STATISTICA 12.0 (StatSoft, Inc. 2014) and PAST 3.0 (Hammer et al. 2001). 


\section{RESULTS}

\section{Concentrations and possible sources of elements}

The hepatic trace element concentrations in the 22 studied white-tailed eagles were ordered as follows: $\mathrm{S}>\mathrm{K}>\mathrm{Na}>$ $\mathrm{Fe}>\mathrm{Mg}>\mathrm{Ca}>\mathrm{Zn}>\mathrm{Cu}>\mathrm{Mn}>\mathrm{Se}>\mathrm{Pb}>\mathrm{Hg}>\mathrm{Cd}>$ $\mathrm{Cr}>\mathrm{Sr}>\mathrm{V}>\mathrm{Sc}$.

Among the studied individuals, 8 (36.4\%) had Pb concentrations exceeding the background level (i.e., $>6.0 \mathrm{mg} \mathrm{kg}^{-1} \mathrm{dw}$ ), and 7 (31.8\%) showed acute poisoning $\left(>30.0 \mathrm{mg} \mathrm{kg}^{-1} \mathrm{dw}\right.$ ), with very high values in 2 individuals (180.3 and $188.6 \mathrm{mg} \mathrm{kg}^{-1}$ ) (Table 3). Generally, 8 (53.3\%) adults and none of the immatures had $\mathrm{Pb}$ levels exceeding the background, and 7 (46.7\%) adults had $\mathrm{Pb}$ levels exceeding the criterion for acute poisoning. A hepatic $\mathrm{Pb}$ concentration of $5.54 \mathrm{mg} \mathrm{g}^{-1} \mathrm{dw}$ was found in a single immature bird.

In the case of $\mathrm{Cd}$ and $\mathrm{Hg}$, the hepatic levels found in the studied individuals were within the background concentration range (Table 3). Two immatures showed 5.19 and $5.45 \mathrm{mg} \mathrm{g}^{-1} \mathrm{dw}$ of hepatic $\mathrm{Hg}$, which were the highest $\mathrm{Hg}$ concentrations observed in this study. High positive relationships were found between $\mathrm{Pb}$ and $\mathrm{Fe}$ (Spearman rank correlation, $\left.r_{\mathrm{s}}=0.81\right), \mathrm{Mg}$ and $\mathrm{Cr}\left(r_{\mathrm{s}}=0.81\right), \mathrm{Fe}$ and $\mathrm{Zn}$ $\left(r_{\mathrm{s}}=0.80\right), \mathrm{Fe}$ and $\mathrm{Cd}\left(r_{\mathrm{s}}=0.79\right), \mathrm{Cd}$ and $\mathrm{Zn}\left(r_{\mathrm{s}}=0.75\right)$, $\mathrm{K}$ and $\mathrm{Mg}\left(r_{\mathrm{s}}=0.75\right), \mathrm{K}$ and $\mathrm{Fe}\left(r_{\mathrm{s}}=0.74\right), \mathrm{Ca}$ and $\mathrm{Sr}$ $\left(r_{\mathrm{s}}=0.72\right)$, and $\mathrm{Cr}$ and $\mathrm{Zn}\left(r_{\mathrm{s}}=0.71\right)$ (Table 4).

Principal component analysis revealed that $84.4 \%$ of the total variance was explained by the two first axes (Table 3). Samples from the adults generally clustered in different positions than those from the immatures (Fig. 2). PC1 explained $69.3 \%$ of the total variance and showed a strong positive correlation with $\mathrm{Pb}(r=0.91)$. PC2 explained $15.0 \%$ of the total variance and was highly negatively correlated with $\mathrm{Hg}(r=-0.79)$ (Table 5).
The majority of the immatures were characterized by low values of $\mathrm{PC} 1$ and $\mathrm{PC} 2$, i.e., by high concentrations of $\mathrm{Hg}$ and low concentrations of $\mathrm{Pb}$. The largest group of adults (clustered in the right-hand part of the graph) was characterized by high $\mathrm{PC} 1$ values, reflecting high $\mathrm{Pb}$ concentrations. A second group of adults (clustered in the lefthand part of the graph) was characterized by low $\mathrm{Pb}$ values.

The $\mathrm{Hg} / \mathrm{Se}$ molar ratio was calculated for all the examined liver samples and amounted to $\leq 0.2$ in $68 \%$ of the livers. The geometric mean calculated over all specimens was 0.12 (range: $0.01-0.64$ ).

\section{Intergroup differences}

The concentrations of all studied elements were significantly affected by age (PERMANOVA on ln-transformed data; Bray-Curtis similarity: $F_{1,21}=3.53, P=0.006$ ). No significant influence of sex or an age $\mathrm{x}$ sex interaction on element concentrations (PERMANOVA, all $P>0.72$ ) was found. The SIMPER analysis (Bray-Curtis similarity) showed that $\mathrm{Pb}, \mathrm{Hg}$, and $\mathrm{Cd}$ contributed the most $(24,11$, and $9 \%$, respectively) to the pattern of dissimilarity between age groups.

Univariate analyses performed separately for particular elements revealed significant age effect (ANOVA/PERMANOVA, all $P<0.05)$ for 7 elements $(\mathrm{Ca}, \mathrm{Cd}, \mathrm{Cu}, \mathrm{Fe}$, $\mathrm{Pb}, \mathrm{Se}$, and $\mathrm{Zn}$ ) (Table 6). Neither sex nor age $\mathrm{x}$ sex interaction affected hepatic concentration of those elements significantly (ANOVA/PERMANOVA, all $P>0.05$ ). Hepatic concentrations of $\mathrm{Cr}, \mathrm{Hg}, \mathrm{K}, \mathrm{Mg}, \mathrm{Mn}, \mathrm{Na}, \mathrm{S}, \mathrm{Sc}$, $\mathrm{Sr}$, and $\mathrm{V}$ were not affected significantly by age, sex, or age $\mathrm{x}$ sex interactions (ANOVA, all $P>0.05$ ).

Adults had higher hepatic concentrations of $\mathrm{Ca}$ (ANOVA on Box-Cox-transformed data: $F_{1,21}=4.45$, $P=0.049$ ), Cd (ANOVA: $F_{1,21}=62.0, P<0.0001$ ), $\mathrm{Fe}$ (one-way PERMANOVA: $F=8.90, \quad P=0.009$ ), $\quad \mathrm{Pb}$

Table 3 Background and toxic concentrations $\left(\mathrm{mg} \mathrm{kg}^{-1} \mathrm{dw}\right)$ of lead, cadmium, and mercury in avian livers [reference values according to Martin et al. 2008 (A), Guitart et al. 1994 (B), Scheuhammer 1987 (C), and (D) Shore et al. (2011)] and their frequencies in livers of the studied white-tailed eagles wintering in Eastern Poland

\begin{tabular}{|c|c|c|c|c|}
\hline \multirow[t]{2}{*}{ Element } & \multicolumn{4}{|c|}{ Concentration level $\left(\mathrm{mg} \mathrm{kg}^{-1} \mathrm{dw}\right)$} \\
\hline & Background & Subclinical toxicity & Moderate clinical poisoning & Acute clinical poisoning \\
\hline \multicolumn{5}{|l|}{$\mathrm{Pb}$} \\
\hline Reference values & $0-6(\mathrm{~A})$ & $6-20(B)$ & $20-30(\mathrm{~B})$ & $>30(\mathrm{~A}, \mathrm{~B})$ \\
\hline Frequency in livers of white-tailed eagles & $63.6 \%$ & $4.6 \%$ & - & $31.8 \%$ \\
\hline \multicolumn{5}{|l|}{$\mathrm{Cd}$} \\
\hline Reference values & $0-3.0(\mathrm{C})$ & $>3.0(\mathrm{C})$ & - & - \\
\hline Frequency in livers of white-tailed eagles & $100.0 \%$ & - & - & - \\
\hline \multicolumn{5}{|l|}{$\mathrm{Hg}$} \\
\hline Reference values & $0-6.7$ (D) & $>6.7$ (D) & - & $>67.0$ (D) \\
\hline Frequency in livers of white-tailed eagles & $100.0 \%$ & - & - & - \\
\hline
\end{tabular}


Table 4 Spearman correlation coefficients $\left(r_{\mathrm{s}}\right)$ for all elements detected in white-tailed eagles. Strengths of significant correlations $(P<0.05)$ : bolded-high correlation $\left(r_{\mathrm{s}}=|0.71-0.90|\right)$, underlined-moderate correlation $\left(r_{\mathrm{s}}=|0.51-0.70|\right)$, and italicized-low correlation $\left(r_{\mathrm{s}}=|0.31-0.50|\right)$ (according to Hinkle et al. 2003)

\begin{tabular}{|c|c|c|c|c|c|c|c|c|c|c|c|c|c|c|c|c|c|}
\hline Element & $\mathrm{K}$ & $\mathrm{S}$ & $\mathrm{Na}$ & $\mathrm{Ca}$ & $\mathrm{Sc}$ & $\mathrm{Cd}$ & $\mathrm{Cr}$ & $\mathrm{Cu}$ & $\mathrm{Fe}$ & $\mathrm{Hg}$ & $\mathrm{Mg}$ & Mn & $\mathrm{Pb}$ & $\mathrm{Se}$ & $\mathrm{Sr}$ & $\mathrm{V}$ & $\mathrm{Zn}$ \\
\hline $\mathrm{K}$ & 1.00 & $\underline{0.51}$ & 0.25 & -0.04 & 0.00 & $\underline{0.70}$ & $\underline{0.55}$ & -0.08 & 0.74 & 0.05 & 0.75 & $\underline{0.58}$ & $\underline{0.60}$ & $-\underline{0.69}$ & 0.31 & 0.40 & $\underline{0.62}$ \\
\hline$S$ & $\underline{0.51}$ & 1.00 & 0.39 & 0.16 & 0.25 & 0.18 & 0.16 & 0.38 & 0.43 & 0.37 & $\underline{0.56}$ & $\underline{0.57}$ & 0.46 & $-\underline{0.65}$ & 0.21 & 0.38 & 0.28 \\
\hline $\mathrm{Na}$ & 0.25 & 0.39 & 1.00 & $-\underline{0.53}$ & 0.24 & 0.01 & -0.02 & 0.37 & 0.39 & 0.04 & 0.26 & 0.31 & 0.40 & -0.12 & -0.29 & 0.38 & 0.10 \\
\hline $\mathrm{Ca}$ & -0.04 & 0.16 & $-\underline{0.53}$ & 1.00 & -0.25 & 0.34 & 0.07 & -0.49 & 0.03 & -0.06 & -0.08 & -0.32 & 0.08 & -0.46 & 0.72 & 0.15 & 0.26 \\
\hline $\mathrm{Sc}$ & 0.00 & 0.25 & 0.24 & -0.25 & 1.00 & -0.14 & 0.03 & 0.24 & -0.08 & 0.13 & 0.08 & 0.43 & -0.11 & 0.06 & -0.25 & -0.19 & -0.21 \\
\hline $\mathrm{Cd}$ & $\underline{0.70}$ & 0.18 & 0.01 & 0.34 & -0.14 & 1.00 & $\underline{0.58}$ & $-\underline{0.52}$ & 0.79 & 0.01 & $\underline{0.56}$ & 0.26 & $\underline{0.64}$ & $-\underline{0.62}$ & $\underline{0.66}$ & 0.27 & 0.75 \\
\hline $\mathrm{Cr}$ & $\underline{0.55}$ & 0.16 & -0.02 & 0.07 & 0.03 & $\underline{0.58}$ & 1.00 & 0.13 & $\underline{0.60}$ & 0.01 & 0.81 & 0.34 & 0.41 & -0.37 & $\underline{0.58}$ & 0.09 & 0.71 \\
\hline $\mathrm{Cu}$ & -0.08 & 0.38 & 0.37 & -0.49 & 0.24 & $-\underline{0.52}$ & 0.13 & 1.00 & -0.05 & 0.27 & 0.29 & 0.37 & -0.13 & 0.19 & -0.32 & -0.11 & -0.07 \\
\hline $\mathrm{Fe}$ & 0.74 & 0.43 & 0.39 & 0.03 & -0.08 & 0.79 & $\underline{0.60}$ & -0.05 & 1.00 & 0.14 & $\underline{0.69}$ & 0.33 & 0.81 & $-\underline{0.58}$ & 0.45 & 0.29 & 0.80 \\
\hline $\mathrm{Hg}$ & 0.05 & 0.37 & 0.04 & -0.06 & 0.13 & 0.01 & 0.01 & 0.27 & 0.14 & 1.00 & 0.19 & 0.41 & 0.46 & -0.06 & -0.02 & -0.47 & -0.21 \\
\hline $\mathrm{Mg}$ & 0.75 & $\underline{0.56}$ & 0.26 & -0.08 & 0.08 & $\underline{0.56}$ & 0.81 & 0.29 & $\underline{0.69}$ & 0.19 & 1.00 & $\underline{0.66}$ & $\underline{0.56}$ & $-\underline{0.54}$ & 0.43 & 0.29 & 0.64 \\
\hline $\mathrm{Mn}$ & $\underline{0.58}$ & $\underline{0.57}$ & 0.31 & -0.32 & 0.43 & 0.26 & 0.34 & 0.37 & 0.33 & 0.41 & $\underline{0.66}$ & 1.00 & 0.33 & -0.41 & -0.10 & 0.05 & 0.12 \\
\hline $\mathrm{Pb}$ & $\underline{0.60}$ & 0.46 & 0.40 & 0.08 & -0.11 & $\underline{0.64}$ & 0.41 & -0.13 & 0.81 & 0.46 & $\underline{0.56}$ & 0.33 & 1.00 & $-\underline{0.64}$ & 0.30 & 0.18 & 0.42 \\
\hline $\mathrm{Se}$ & $-\underline{0.69}$ & $-\underline{0.65}$ & -0.12 & -0.46 & 0.06 & $-\underline{0.62}$ & -0.37 & 0.19 & $-\underline{0.58}$ & -0.06 & $-\underline{0.54}$ & -0.41 & $-\underline{0.64}$ & 1.00 & -0.46 & -0.48 & $-\underline{0.52}$ \\
\hline $\mathrm{Sr}$ & 0.31 & 0.21 & -0.29 & 0.72 & -0.25 & $\underline{0.66}$ & $\underline{0.58}$ & -0.32 & 0.45 & -0.02 & 0.43 & -0.10 & 0.30 & -0.46 & 1.00 & 0.21 & $\underline{0.70}$ \\
\hline V & 0.40 & 0.38 & 0.38 & 0.15 & -0.19 & 0.27 & 0.09 & -0.11 & 0.29 & -0.47 & 0.29 & 0.05 & 0.18 & -0.48 & 0.21 & 1.00 & 0.45 \\
\hline $\mathrm{Zn}$ & $\underline{0.62}$ & 0.28 & 0.10 & 0.26 & -0.21 & 0.75 & 0.71 & -0.07 & 0.80 & -0.21 & $\underline{0.64}$ & 0.12 & 0.42 & -0.52 & $\underline{0.70}$ & 0.45 & 1.00 \\
\hline
\end{tabular}

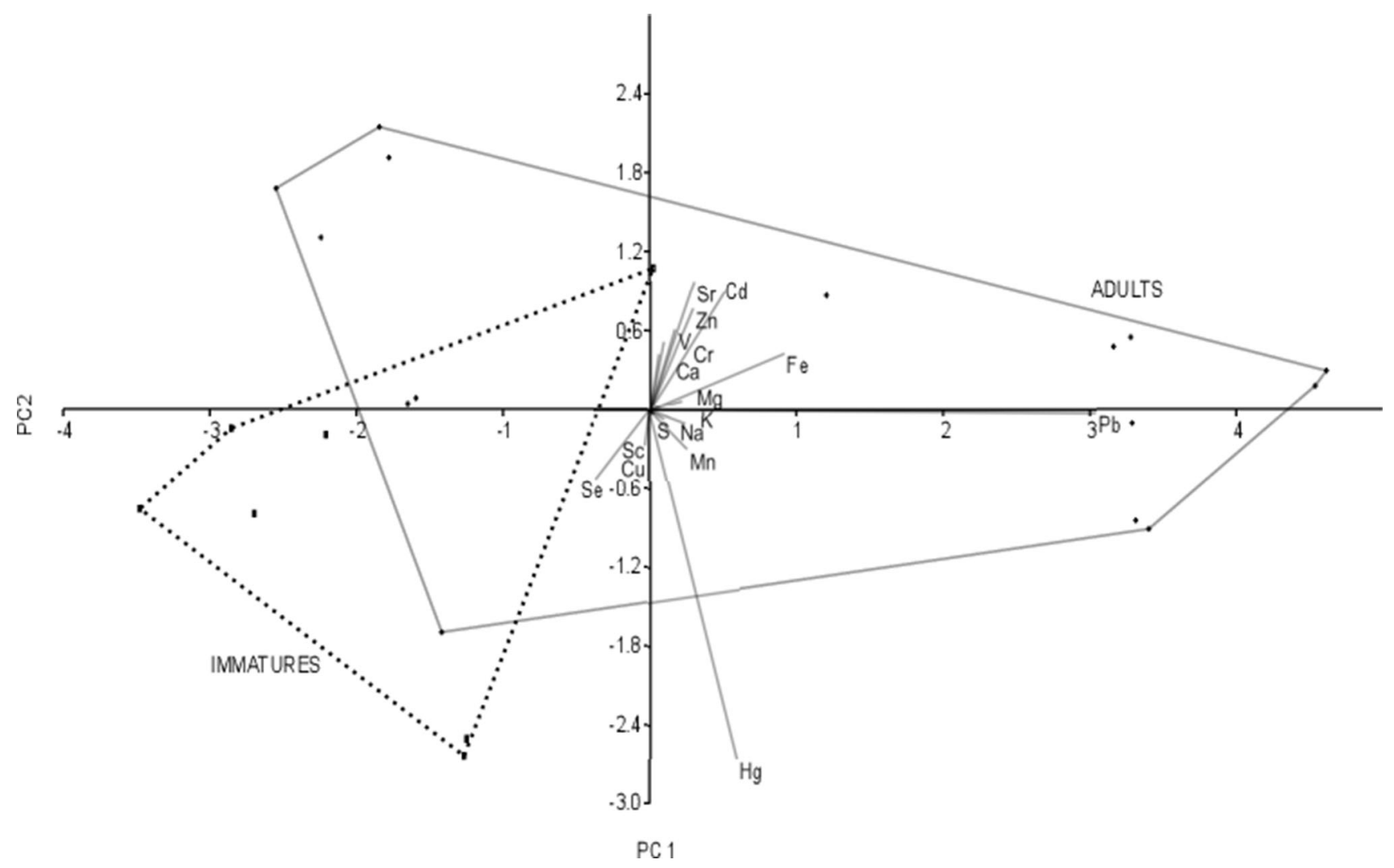

Fig. 2 PCA biplot of element concentrations in the livers of immature and adult white-tailed eagles wintering in Eastern Poland. Convex hulls contain all samples representing a particular age category. Samples collected from adults and immatures are presented as points, and elements are presented as vectors 
Table 5 Values of the principal component loadings for the elements (ln transformed) in the studied white-tailed eagles; strongly and highly correlated values $(r>10.70 \mathrm{l})$

\begin{tabular}{lcr}
\hline Element & Axis 1 & Axis 2 \\
\hline $\mathrm{K}$ & 0.07 & -0.03 \\
$\mathrm{~S}$ & 0.03 & -0.02 \\
$\mathrm{Na}$ & 0.01 & -0.01 \\
$\mathrm{Ca}$ & 0.02 & 0.13 \\
$\mathrm{Sc}$ & -0.01 & -0.08 \\
$\mathrm{Cd}$ & 0.15 & 0.27 \\
$\mathrm{Cr}$ & 0.03 & 0.15 \\
$\mathrm{Cu}$ & 0.00 & -0.18 \\
$\mathrm{Fe}$ & 0.27 & 0.13 \\
$\mathrm{Hg}$ & 0.18 & $-\mathbf{0 . 7 9}$ \\
$\mathrm{Mg}$ & 0.07 & 0.02 \\
$\mathrm{Mn}$ & 0.08 & -0.09 \\
$\mathrm{~Pb}$ & $\mathbf{0 . 9 1}$ & -0.01 \\
$\mathrm{Se}$ & -0.11 & -0.16 \\
$\mathrm{Sr}$ & 0.09 & 0.29 \\
$\mathrm{~V}$ & 0.05 & 0.18 \\
$\mathrm{Zn}$ & 0.09 & 0.23 \\
Eigen values & 7.5 & 1.6 \\
$\mathrm{Total}$ variance explained $(\%)$ & 69.3 & 15.0 \\
\hline
\end{tabular}

(ANOVA on Box-Cox transformed data: $F_{1,21}=6.38$, $P=0.02$ ), and Zn (ANOVA on Box-Cox transformed data: $F_{1,21}=4.48, P=0.048$ ) than immatures (Table 5).

Immatures had higher hepatic concentrations of $\mathrm{Cu}$ (ANOVA: $F_{1,18}=14.6, P=0.001$ ), and Se (ANOVA: $F_{1,21}=5.87, P=0.03$ ) than adults (Table 5).

\section{Regional differences in element concentrations}

Inter-regional differences in the hepatic concentrations of some elements in white-tailed eagles were found. Higher concentrations of $\mathrm{K}, \mathrm{S}, \mathrm{Cd}, \mathrm{Fe}, \mathrm{Mg}, \mathrm{Sr}$, and $\mathrm{Zn}$ were found in the northern region, and higher concentrations of $\mathrm{Se}$ were found in the southern region (Mann-Whitney $U$ test: $P<0.05$; Table 7$)$. There was a tendency $(P=0.06)$ for individuals from the northern region to accumulate higher $\mathrm{Pb}$ concentrations, but the hepatic levels of $\mathrm{Na}, \mathrm{Ca}, \mathrm{Cr}, \mathrm{Cu}$, $\mathrm{Hg}, \mathrm{Mn}, \mathrm{Sc}$, and $\mathrm{V}$ in eagles from the northern and southern regions were similar (Table 7 ).

The highest $\mathrm{Hg}$ concentrations were found in immatures from locations in the southern region situated close to the Bug River in Kryłów and Włodawa. The highest hepatic concentrations of $\mathrm{Pb}$ were recorded in adults collected in the Masurian Lake District (central part of the northern region). A group of adults from the left-hand part of the

Table 6 Concentrations $\left(\mathrm{mg} \mathrm{kg}^{-1} \mathrm{dw}\right)$ of the studied elements in adult and immature white-tailed eagles. Age differences detected by ANOVA or PERMANOVA $\left({ }^{\mathrm{p}}\right)$ at the following $P$ levels $(\mathrm{Fe}): * P<0.05$, $* * P<0.01$, and $* * * P \leq 0.001$

\begin{tabular}{|c|c|c|c|c|c|c|c|c|}
\hline \multirow[t]{2}{*}{ Element } & \multicolumn{4}{|c|}{ Immatures $(N=7)$} & \multicolumn{4}{|c|}{ Adults $(N=15)$} \\
\hline & Mean & SD & Min & Max & Mean & SD & Min & Max \\
\hline $\mathrm{Ca}$ & $253.4^{*}$ & 125.9 & 132.0 & 471.3 & $397.6^{*}$ & 275.2 & 224.6 & 1075.9 \\
\hline $\mathrm{Cd}$ & $0.16^{* * * *}$ & 0.04 & 0.13 & 0.24 & $0.53 * * *$ & 0.14 & 0.19 & 0.70 \\
\hline $\mathrm{Cr}$ & 0.27 & 0.06 & 0.16 & 0.32 & 0.44 & 0.28 & 0.22 & 1.20 \\
\hline $\mathrm{Cu}$ & $23.0 * * *$ & 6.6 & 13.1 & 31.8 & $13.1 * * *$ & 4.9 & 6.3 & 20.0 \\
\hline $\mathrm{Fe}^{\mathrm{p}}$ & $1466.5 * *$ & 175.4 & 1325.3 & 1846.0 & $4920.5^{* *}$ & 3534.4 & 1118.0 & 11841.2 \\
\hline $\mathrm{Hg}$ & 2.2 & 2.2 & 0.3 & 5.5 & 1.6 & 1.5 & 0.1 & 4.7 \\
\hline $\mathrm{K}$ & 8232.1 & 637.7 & 7278.2 & 9052.7 & 9612.2 & 2827.8 & 2419.9 & 12550.0 \\
\hline $\mathrm{Mg}$ & 625.6 & 63.8 & 544.1 & 706.1 & 754.5 & 199.8 & 502.6 & 1019.7 \\
\hline Mn & 9.6 & 2.8 & 5.1 & 12.8 & 11.4 & 4.8 & 6.0 & 18.5 \\
\hline $\mathrm{Na}$ & 3874.3 & 225.4 & 3516.7 & 4139.6 & 3871.1 & 351.1 & 3462.3 & 4613.6 \\
\hline $\mathrm{Pb}$ & $1.3 * *$ & 1.9 & 0.1 & 5.5 & $48.7 * *$ & 63.6 & 0.4 & 188.6 \\
\hline $\mathrm{S}$ & 9234.7 & 885.3 & 7886.0 & 10023.0 & 8712.4 & 1395.0 & 7116.7 & 10960.0 \\
\hline $\mathrm{Sc}$ & 0.01 & 0.00 & 0.01 & 0.02 & 0.01 & 0.01 & 0.01 & 0.03 \\
\hline $\mathrm{Se}$ & $5.2 * *$ & 2.6 & 2.6 & 9.1 & $3.2 * *$ & 1.1 & 1.6 & 5.2 \\
\hline $\mathrm{Sr}$ & 0.20 & 0.10 & 0.07 & 0.32 & 0.37 & 0.21 & 0.11 & 0.69 \\
\hline V & 0.20 & 0.11 & 0.07 & 0.33 & 0.18 & 0.072 & 0.08 & 0.32 \\
\hline $\mathrm{Zn}$ & $116.3^{*}$ & 34.4 & 69.7 & 159.4 & $183.0 *$ & 73.0 & 71.3 & 301.5 \\
\hline
\end{tabular}


Table 7 Concentrations $\left(\mathrm{mg} \mathrm{kg}^{-1} \mathrm{dw}\right)$ of the studied elements in adult and immature white-tailed eagles combined in the northern $(\mathrm{N})$ and southern (S) parts of the study area. Mann-Whitney test for inter-regional differences. Significant differences $(P<0.05)$ are bolded

\begin{tabular}{|c|c|c|c|c|c|c|c|c|}
\hline \multirow[t]{2}{*}{ Element } & \multicolumn{3}{|c|}{ Region $\mathrm{N}(N=14)$} & \multicolumn{3}{|c|}{ Region $\mathrm{S}(N=8)$} & \multicolumn{2}{|c|}{ Mann-Whitney test } \\
\hline & Median & Min & Max & Median & Min & Max & $U$ & $P$ \\
\hline $\mathrm{K}$ & 10291.4 & 2419.9 & 12550.0 & 7914.9 & 6485.8 & 10216.7 & 22.0 & 0.022 \\
\hline $\mathrm{S}$ & 9625.8 & 7219.3 & 10960.0 & 7907.5 & 7116.7 & 9793.3 & 26.0 & 0.044 \\
\hline $\mathrm{Na}$ & 3833.5 & 3545.3 & 4406.0 & 3761.8 & 3462.3 & 4613.6 & 46.0 & 0.517 \\
\hline $\mathrm{Ca}$ & 288.8 & 178.1 & 1017.7 & 243.1 & 132.0 & 1075.9 & 37.0 & 0.207 \\
\hline Sc & 0.0 & 0.0 & 0.0 & 0.0 & 0.0 & 0.0 & 52.5 & 0.779 \\
\hline $\mathrm{Cd}$ & 0.5 & 0.2 & 0.7 & 0.2 & 0.1 & 0.5 & 16.5 & 0.008 \\
\hline $\mathrm{Cr}$ & 0.4 & 0.2 & 1.0 & 0.3 & 0.2 & 1.2 & 32.5 & 0.116 \\
\hline $\mathrm{Cu}$ & 15.3 & 6.6 & 28.2 & 17.8 & 6.3 & 31.8 & 44.0 & 0.433 \\
\hline $\mathrm{Fe}$ & 5003.2 & 1118.0 & 11841.2 & 1466.5 & 1175.3 & 3049.0 & 22.0 & 0.022 \\
\hline $\mathrm{Hg}$ & 0.9 & 0.1 & 4.7 & 1.4 & 0.2 & 5.5 & 49.5 & 0.682 \\
\hline $\mathrm{Mg}$ & 766.0 & 533.4 & 1019.7 & 564.1 & 502.6 & 743.6 & 21.0 & 0.019 \\
\hline $\mathrm{Pb}$ & 36.9 & 0.1 & 188.6 & 0.7 & 0.2 & 1.4 & 28.0 & 0.061 \\
\hline $\mathrm{Mn}$ & 10.2 & 5.1 & 18.5 & 8.2 & 6.0 & 12.6 & 38.0 & 0.232 \\
\hline $\mathrm{Se}$ & 2.9 & 1.6 & 4.6 & 4.4 & 3.0 & 9.1 & 15.0 & 0.006 \\
\hline $\mathrm{Sr}$ & 0.3 & 0.1 & 0.7 & 0.2 & 0.1 & 0.7 & 38.0 & 0.034 \\
\hline $\mathrm{V}$ & 0.2 & 0.1 & 0.3 & 0.2 & 0.1 & 0.3 & 24.5 & 0.231 \\
\hline $\mathrm{Zn}$ & 170.2 & 72.0 & 301.5 & 95.1 & 69.7 & 252.8 & 24.0 & 0.032 \\
\hline
\end{tabular}

graph representing low $\mathrm{Pb}$ values originated from the southern region and the western part of the northern region.

\section{Relationships between element concentrations and landscape features}

For all individuals combined $(N=22)$, a significant positive relationship was found between the relative area of wetlands and the $\mathrm{Pb}$ concentration (Spearman correlation coefficient: $r_{\mathrm{s}}=0.45, P=0.04$ ), and there was also a significant positive relationship between the relative area of water bodies and the $\mathrm{Cd}$ concentration $\left(r_{\mathrm{s}}=0.44\right.$, $P=0.04)$. A series of significant negative correlations was found between the relative area of artificial surfaces and $\mathrm{K}$ ( $\left.r_{\mathrm{s}}=-0.44, P=0.04\right), \mathrm{S}\left(r_{\mathrm{s}}=-0.57, P=0.005\right)$, and $\mathrm{Pb}$ $\left(r_{\mathrm{s}}=-0.59, P=0.004\right)$, and there was one positive correlation with $\mathrm{Se}\left(r_{\mathrm{s}}=0.66, P=0.0009\right)$.

No significant relationships were found between the concentration of any element and the relative area of forest (Spearman correlations, all $P>0.22$ ), pasture (all $P>0.11$ ), or arable land (all $P>0.41$ ).

\section{DISCUSSION}

To our knowledge, this is the first study to investigate the possible sources of trace elements in the livers of whitetailed eagles in Central Europe and one of the few studies to investigate the concentrations of elements in this species in relation to sex and age. This study presents element contamination levels in winter in a habitat mosaic of forest, lakes, and extensive agriculture that is characteristic of Eastern Poland.

PCA and SIMPER analyses revealed the two main elements that differed the most in the livers of the studied white-tailed eagles: $\mathrm{Pb}$ and $\mathrm{Hg}$; most individuals with a high level of one of these elements also had a low value for the other, which suggests different sources of origin for both elements (Kalisinska et al. 2014a). Although fertilizers are often blamed for being a source of $\mathrm{Hg}$ contamination (Mortvedt 1995; Otero et al. 2005) and coal combustion is cited as a significant source of $\mathrm{Hg}$ emissions (Pacyna et al. 2006; Hlawiczka and Cenowski 2013; Zajusz-Zubek and Konieczyński 2014) in Poland, the main source of $\mathrm{Hg}$ contamination in this study was aquatic prey (fish and birds). This was previously reported for whitetailed eagles from Western Poland (Falandysz et al. 2001) and can be explained by the transport of highly contaminated water in the Bug River northwards from the Ukrainian Lviv-Volyn Coal Basin (Wolska et al. 2008; Skorbiłowicz 2014).

The significant correlations of the hepatic $\mathrm{Pb}$ concentration with the relative area of wetlands (positive) and artificial surfaces (negative) indicate a non-industrial aquatic origin of this element in the white-tailed eagle. In the areas of Eastern Poland with ice-covered lakes in winter, white-tailed eagles mainly forage on the carrion of ungulates and dead mute swans and mallards (Zawadzka 
1999; Zawadzka et al. 2006), which may be contaminated by lead from shot hunting ammunition (Perrins et al. 2003; Mateo 2009) and corresponds with the hepatic Pb levels in eagles from the Masurian Lake District.

\section{Age and sex differences in element concentration levels}

Significant age-related differences in the hepatic concentrations of some elements were found in adult eagles, which exhibited higher levels of $\mathrm{Ca}, \mathrm{Cd}, \mathrm{Fe}, \mathrm{Pb}$, and $\mathrm{Zn}$ and lower concentrations of $\mathrm{Cu}$ and $\mathrm{Se}$ compared with immatures. Similar age-related differences in renal and hepatic $\mathrm{Cd}$ concentrations have been found in another raptor, the common buzzard (Carneiro et al. 2014), and lower hepatic concentrations of $\mathrm{Cd}, \mathrm{Pb}, \mathrm{Cu}$, and $\mathrm{Fe}$ have also been reported in immature common kestrels from South Korea (Kim and Oh 2015). However, in some studies, including of Haliaeetus sp. eagles, no age-related differences have been found; no significant age-related differences in $\mathrm{Cd}$, $\mathrm{Cu}, \mathrm{Fe}, \mathrm{Hg}, \mathrm{Mg}, \mathrm{Mn}, \mathrm{Mo}, \mathrm{Se}$, and $\mathrm{Zn}$ concentrations have been found in the livers of the American counterpart to the white-tailed eagle, the bald eagle, Haliaeetus leucocephalus, from Alaska (Stout and Trust 2002). Similar hepatic $\mathrm{Pb}$ levels have been reported in immature and adult white-tailed eagles from Sweden (Helander et al. 2009). Therefore, the differences in the contamination levels between adults and immatures observed in our study may be explained by age-related differences in wintering strategies and hunting skills. Sedentary adults wintering in their territories forage in well-known feeding areas. By contrast, migrating and less-experienced immatures hunt in new areas (Cramp and Simmons 1980; Mizera 2004; Nadjafzadeh et al. 2016a). Moreover, experienced adults are more successful when hunting for agile prey, such as waterfowl (Nadjafzadeh et al. 2013; Nadjafzadeh et al. 2016a); many such game birds are often contaminated with $\mathrm{Pb}$.

Similar to other studies on raptors (e.g., Castro et al. 2011; Bedrosian et al. 2012), this study did not find significant sex-related differences in hepatic element concentrations. Studies of German and Austrian white-tailed eagles revealed no sex-related differences in the hepatic concentrations of $\mathrm{Cd}, \mathrm{Hg}$, and $\mathrm{Pb}$ (Kenntner et al. 2001), and similar hepatic levels of $\mathrm{Pb}$ regardless of sex have been reported in Sweden (Helander et al. 2009). Additionally, sex-related differences in $\mathrm{Pb}$ hepatic concentrations have been reported to be rare in other raptors (Franson et al. 1983; Wayland et al. 1999; Castro et al. 2011; Carneiro et al. 2014). The lack of sex-related differences in whitetailed eagles may be explained by the only slight reverse sexual dimorphism (RSD), which does not result in differences in foraging ecology. Sex-related differences in prey preferences have been documented in raptor species with more pronounced RSD (e.g., Newton 1979; Sunde et al. 2003; Bujoczek and Ciach 2009), which allows for foraging niches to be segregated to avoid competition (Temeles 1986; Sunde et al. 2003).

\section{Concentrations of selected elements}

\section{Sulfur}

The liver serves as a target for the deposition of many substances that are important for the organism (including macro- and microelements), and it is also the organ involved in detoxification processes (the elimination of toxic elements such as $\mathrm{Cd}, \mathrm{Hg}$, and $\mathrm{Pb}$ ). A major chemical property of many toxic metals, including $\mathrm{Cd}, \mathrm{Hg}$, and $\mathrm{Pb}$, is their capacity to strongly bind to thiol residues, which are used by most organisms for detoxification; therefore, heavy metal detoxification by glutathione necessitates high amounts of sulfur (Tamas and Martinoia 2006). Furthermore, the detoxification of metals based on metallothionein, a cysteine-rich protein, is also sulfur-dependent. To cope with this vital sulfur requirement, sulfur metabolism is normally directed to the intake of methionine and cysteine for protein synthesis, but neither cysteine nor methionine is stored in the body. Any dietary excess is readily oxidized to sulfate, excreted in the urine (or reabsorbed depending on dietary levels) or stored in the form of glutathione (Nimni et al. 2007), and these processes are related to the supply of sulfur, which is collected in the form of amino acids, to a healthy body (Nimni et al. 2007, Netto et al. 2014, Toohey 2014). The birds examined in this study accumulated $40-50 \%$ less $\mathrm{S}$ in their livers (Table 6) than eagles from Western Poland (Falandysz et al. 2001) (mean: $17000 \mathrm{mg} \mathrm{kg}^{-1} \mathrm{dw}$ ), which may indicate (in the context of very high levels of hepatic $\mathrm{Pb}$ ) problems in the supply of sulfur necessary for detoxification.

\section{Lead}

The high $\mathrm{Pb}$ concentration levels reported in the presented study (up to $180 \mathrm{mg} \mathrm{kg}^{-1}$ ) may be explained in terms of the high contribution of the carrion of shot game mammals and waterfowl to the winter diet of white-tailed eagles; when fish availability sharply declines, the birds switch to foraging on waterfowl and carrion (van Rijn et al. 2010; Nadjafzadeh et al. 2013). Thus, the highest frequencies of $\mathrm{Pb}$ poisoning in eagles are reported in autumn and winter (Helander et al. 2009; Nadjafzadeh et al. 2013). The $\mathrm{Pb}$ concentrations in individuals collected in the northern part of the study area tended to be higher than those in the southern part. The northern region, the NE Poland, serves 
as the wintering grounds and stop-over site for many waterfowl species (Zawadzka 1999; Zawadzka et al. 2006).The eagles' habit of preying on ducks killed with lead ammunition may explain the elevated $\mathrm{Pb}$ levels in white-tailed eagles from this area. Elevated levels of $\mathrm{Pb}$ in the study area are a consequence of the lack of restrictions on the use of lead hunting ammunition in Poland (in contrast to many other European countries; Mateo 2009). Reports from different countries suggest that the remains of hunted big game mammals may be a significant source of dietary lead exposure for large eagles in areas with low waterfowl availability (Helander et al. 2009; Bedrosian et al. 2012). In the USA, the frequency of lead ingestion in both golden eagles, Aquila chrysaetos, and bald eagles did not drop after lead shot was banned for waterfowl hunting (Kramer and Redig 1997), which indicates mammal carcasses as an alternative source of $\mathrm{Pb}$ exposure. Moreover, areas and periods with a high incidence of lead poisoning in eagles were not correlated with waterfowl hunting in both the western USA and the Great Plains (Miller et al. 1998; Wayland et al. 2003). In our study, the frequency (32\%) of birds with hepatic $\mathrm{Pb}$ levels indicating poisoning (i.e., $>20 \mathrm{mg} \mathrm{kg}^{-1} \mathrm{dw}$ ) is higher than that reported in Germany (24\%; Kenntner et al. 2001) or Sweden (12.5\%; Helander et al. 2009), but similar to the frequency reported for bald eagles from Michigan and Minnesota in the USA (30\%; Nam et al. 2012). Moreover, the frequency of birds with background hepatic $\mathrm{Pb}$ concentrations, i.e., $<6.0 \mathrm{mg} \mathrm{kg}^{-1}$, was lower in our study (64\%) compared with Sweden (85\%; Helander et al. 2009). Severe $\mathrm{Pb}$ intoxication can cause serious disorders, such as depression, paralysis, weakness of the legs or wings, and neuropathological damage in the brain (encephalopathy), which is manifested as an impairment of the blood-brain barrier, as well as enlargement of the gall bladder (Helander et al. 2009; Stauber et al. 2010; Nam et al. 2012). Thus, $\mathrm{Pb}$ contamination may considerably affect the eagle mortality rate.

\section{Cadmium}

The liver is one of the two main organs subjected to $\mathrm{Cd}$ accumulation (Garcia-Fernandez et al. 1996; Nam et al. 2005a, b; Wayland and Scheuhammer 2011); the mean hepatic Cd concentration ( $\mathrm{mg} \mathrm{kg}^{-1} \mathrm{dw}$ ) found in this study (0.35) was approximately 9 times lower than that indicative of increased environmental exposure (Burgat 1990; Battaglia et al. 2005). By contrast, lower arithmetic mean Cd concentrations $(0.15)$ have been reported for white-tailed eagles from Northwestern Poland (Falandysz et al. 2001). The positive relationship between the relative area of water bodies and hepatic $\mathrm{Cd}$ concentrations reported in our study may be explained in terms of waterfowl hunting in lakeland areas. The $\mathrm{Cd}$ concentrations in the kidneys of most wild freshwater ducks, which are the primary prey of the studied species, are relatively high, i.e., 2-8 (Scheuhammer 1987; Binkowski et al. 2013), and Cd bioaccumulation is accompanied by changes in the levels of some essential elements, including Zn (Brzoska and Moniuszko-Jakoniuk 2001), which was reflected in our study in the significantly high correlation between both elements $\left(r_{\mathrm{s}}=0.75\right)$. Positive correlations between tissue concentrations of $\mathrm{Cd}$ with $\mathrm{Zn}$ have been reported for many species of birds (Furness 1996; Nam and Lee 2006; Kim et al. 2008, 2009). Increased liver concentrations of $\mathrm{Zn}$ (Chmielnicka et al. 1989; Lopez-Alonso et al. 2002) decrease the availability of this element for other tissues (for example, bone) and many biochemical processes (Brzoska and MoniuszkoJakoniuk 2001), but an increased Zn supply may reduce $\mathrm{Cd}$ absorption and accumulation, thus preventing or reducing the adverse actions of $\mathrm{Cd}$. However, $\mathrm{Zn}$ deficiency can intensify $\mathrm{Cd}$ accumulation and toxicity (Brzoska and Moniuszko-Jakoniuk 2001). Studies of mammals have revealed that $\mathrm{Se}$ can enhance $\mathrm{Cd}$ accumulation in mammal tissues and prevent acute Cd toxicity (Wahba et al. 1993), which corresponds with our results showing a negative correlation between $\mathrm{Cd}$ and $\mathrm{Se}$ in the livers of the examined white-tailed eagles.

\section{Mercury}

Mean hepatic concentrations $\left(\mathrm{mg} \mathrm{kg}^{-1} \mathrm{dw}\right)$ of $\mathrm{Hg}$, both in our study (1.046) and in a study from the South Baltic (mean 1.91; Kalisinska et al. 2014a), confirm a current decrease in environmental $\mathrm{Hg}$ concentrations, perhaps due to various activities aimed at limiting its industrial emissions. At the beginning of the 1990s, white-tailed eagles from Northwestern Poland accumulated an average of 5.8 (range: 0.6-21.0) of hepatic Hg (Falandysz et al. 2001). Bald eagles from British Columbia (Canada) have been shown to accumulate $\sim 10$ times more $\mathrm{Hg}$ (mean: 11.8, range: $0.5-17.2$ ) than the birds in our study (Weech et al. 2003). The accumulation of $\mathrm{Hg}$ is strongly determined by local conditions. Thus, the level of contamination observed in the studied birds from Eastern Poland, which has a low level of industrialization, was relatively low $(<5.45)$.

The main source of $\mathrm{Hg}$ for the examined white-tailed eagles was aquatic prey, including fish and birds, as indicated by the possible accumulation of this element in their internal organs. Łuczyńska (2005) reported that the total mercury content $\left(\mathrm{mg} \mathrm{kg}^{-1} \mathrm{dw}\right)$ ranged from 0.076 to 0.902 in the muscle of pike, from 0.074 to 0.278 in roach, and from 0.104 to 1.277 in perch, Perca fluviatilis. Kalisinska et al. (2013) determined the $\mathrm{Hg}$ concentrations in the following organs in mallard, a duck that is frequently captured 
by white-tailed eagles: breast muscle (median: 0.114 , range: 0.008-0.938), liver (median: 0.203, range: 0.016-0.966), and kidney (median: 0.270, range: 0.010-1.499).

Mercury speciation was not performed in the present study; therefore, we only had information concerning the total amount of $\mathrm{Hg}$ ( $\mathrm{THg}$ ). However, this was sufficient to estimate the threat from this element to the studied eagles. All forms of mercury are toxic to birds and mammals, but one should pay particular attention to the toxicity of methylmercury ( $\mathrm{MeHg}$ ) due to its high bioavailability and neurotoxicity (Nam et al. 2012). Inorganic $\mathrm{Hg}(\mathrm{InHg}$ ) that has been subjected to bio-transformation by microorganisms in sediments is the main source of $\mathrm{MeHg}$ (Wiener et al. 2003). Considering the data obtained in this study, it should be noted that $\mathrm{MeHg}$ occurs at a high ratio in fish muscles ( $>80 \%$ of $\mathrm{THg}$ ) (Kalisinska et al. 2017); methylmercury demethylation occurs in the liver and kidneys, leading to the less toxic $\mathrm{InHg}$, which can be excreted (Wiener et al. 2003).

\section{Selenium}

Poland belongs to a group of countries for which Se deficiency in the environment has been reported (Nowakowska et al. 2014; Kalisinska et al. 2014b, c). This study showed that higher hepatic Se levels were found in white-tailed eagles from Southeastern Poland (see Fig. 1) than in those from Northeastern Poland (Table 7). There was a positive relationship between the hepatic Se level and the urbanized area around the sampling sites. This may indicate that coal combustion is a significant selenium source, which has also been reported previously (Hartzell 2014). Especially in Southeastern Poland, the consumption of coal for heating purposes is very high; hard coal fulfills $3 / 4$ of the heating demand in households in the studied region of Lublin (Szul 2011) in contrast to Northeastern Poland, where more frequently wood is used.

Two forms of $\mathrm{Hg}$, inorganic $\mathrm{Hg}$ ( $\mathrm{InHg}$ ) and methylmercury $\mathrm{Hg}$ ( $\mathrm{MeHg}$ ), can inhibit the selenoenzyme glutathione peroxidase, which is crucial for antioxidant regulation (Branco et al. 2012). Therefore, it is important to examine the total $\mathrm{Hg}$ ( $\mathrm{THg}$ ) concentration, as well as the ratio of $\mathrm{THg}$ to total $\mathrm{Se}$; studies of bird livers have shown positive correlations between concentrations of the particular forms of $\mathrm{Hg}$ and total $\mathrm{Hg}(\mathrm{THg})$, as well as between the concentrations of $\mathrm{Se}$ and $\mathrm{THg}$ (Scheuhammer et al. 2008; Kalisinska et al. 2014b, c). The molar ratios of THg to Se obtained in this study correspond to the data obtained for inland and wetland birds, as well as seabirds, for which the reported $\mathrm{Hg}$ :Se molar ratio ranged between 0.1 and 0.2 (Kim et al. 1996; Petrie et al. 2007; Conover and Vest 2009).

\section{Iron}

In the studied white-tailed eagles, a relatively high concentration ( $\mathrm{mg} \mathrm{kg}^{-1} \mathrm{dw}$ ) of Fe (mean 2753) was detected compared with data from Northwestern Poland [mean 1200 (Falandysz et al. 2001); 1726 (Kalisińska et al. 2006)]; similar values (2287) were detected in the livers of common buzzards, Buteo buteo, from the Netherlands (Jager et al. 1996). The hyper-accumulation of $\mathrm{Fe}$ in the studied white-tailed eagles may be explained as a response to $\mathrm{Pb}$ poisoning (Ochiai et al. 1992; Lewis et al. 2001; Kalisinska et al. 2008a). A similar mechanism has also been reported for bats, in which a high level of blood $\mathrm{Pb}$ was accompanied by a high accumulation of $\mathrm{Fe}$ in the liver (Farina et al. 2005); this phenomenon was reflected in this study by a high correlation between both elements $\left(r_{\mathrm{s}}=0.81\right)$. On the other hand, the high accumulation of $\mathrm{Fe}$ may also be indicative of strong bacterial and helminthological infections (Kalisinska et al. 2008a). According to Harrison's rule, large avian species such as white-tailed eagles can host richer parasite communities (Poulin 1998), and whitetailed eagles are hosts of a broad spectrum of endoparasites (Krone et al. 2004, 2006, 2008; Kalisinska et al. 2008b). We do not know the infection status of the studied individuals, but dissection revealed that two individuals with elevated levels $\left(\mathrm{mg} \mathrm{kg}^{-1} \mathrm{dw}\right)$ of both $\mathrm{Fe}$ (4136.5 and 5782.3, respectively) and $\mathrm{Pb}$ (9.78 and 63.56, respectively) had fungal infections in their internal organs.

\section{Copper}

Hepatic accumulation $\left(\mathrm{mg} \mathrm{kg}^{-1} \mathrm{dw}\right)$ of $\mathrm{Cu}$ in the present study (mean: 14.69) was comparable to results for whitetailed eagles from Northwestern Poland (13.0 and 16.08; Falandysz et al. 2001; Kalisińska et al. 2006). Elevated hepatic concentrations of $\mathrm{Cu}$ are related to the depletion of fat and protein resources (Esselink et al. 1995; Jager et al. 1996), as Cu mainly originates from ingested aquatic prey, such as fish and waterbirds. The most important avian prey components of white-tailed eagles in Poland, such as coots and mallards (Zawadzka 1999; Zawadzka et al. 2006), accumulate 16.1 and 39.5-127.0 of hepatic $\mathrm{Cu}$, respectively (Nam et al. 2005a; Kim and Oh 2012; Binkowski et al. 2013). Even higher levels of $\mathrm{Cu}\left(>500 \mathrm{mg} \mathrm{kg}^{-1} \mathrm{dw}\right)$ have been reported in the livers of supplementary whitetailed eagle prey, including the grey heron, Ardea cinerea, and the mute swan, Cygnus color (Horai et al. 2007; Schummer et al. 2011; Komosa et al. 2012), and fish may also serve as an important source of $\mathrm{Cu}$. High accumulation of $\mathrm{Cu}$ and $\mathrm{Mn}$ has been reported in the muscle and livers of fish from Eastern Poland (bream, northern pike), ranging from 6.3 to $167.0 \mathrm{mg} \mathrm{kg}^{-1} \mathrm{dw}$ (Radwan et al. 1990). 


\section{CONCLUSIONS}

In this study, we assessed the hepatic levels of trace elements in white-tailed eagles wintering in relatively unpolluted Northeastern Poland, and we found age-related differences in some element concentrations that may be explained by differences in wintering strategies and hunting skills. Our study confirmed that the internal organs of large raptors, such as the white-tailed eagle, are good bioindicators of environmental contamination. Lead ammunition continues to pose a serious threat to the health and lives of white-tailed eagles in Poland (32\% of the studied individuals had acute lead poisoning). Our results and documented toxic risk for wildlife and human from exposure to lead from ingested shot ammunition (e.g., Knott et al. 2010) indicate a serious need to ban the use of lead hunting ammunition in those parts of Europe (including Poland) where it is still allowed. The regulatory actions adopted by European countries are diverse, resulting from lack of regulations (e.g., Poland) through ban on lead shot for hunting in wetlands, and/or for the hunting of waterbirds to ban to all hunted species and areas (Mateo 2009). The United Nations Convention on Migratory Species, has called to phase out all lead ammunition until 2017. Unfortunately, so far, use of lead ammunition use in the European Union is regulated only on a limited basis (banned in wetlands) under the EU chemicals regulation REACH (Registration, Evaluation, Authorization and Restriction of Chemicals).

We are aware of some limitations of our study. It was based on a non-random sample of the population, i.e., injured birds delivered to a veterinary clinic, sometimes in a sub-lethal state. Some of the studied birds might have been poisoned by food, which may have affected their hepatic element concentrations. However, the study presents current data on elemental contamination in this sentinel species of high conservation priority. The state of its health (i.e., contamination level) is important to assess the condition of its population. The results of our study are important from both an ecotoxicological and a conservation perspective.

\begin{abstract}
Acknowledgements The authors thank the veterinarians from local clinics and rehabilitation centers in Eastern Poland for their help in obtaining the research material. The study was supported by the statutory funds of the Institute of Agrophysics of the Polish Academy of Sciences in Lublin. The study was performed with permission (for the first author) from the Regional Directorate of Nature Protection in Lublin (WPN.6401.224.2014.1).
\end{abstract}

Open Access This article is distributed under the terms of the Creative Commons Attribution 4.0 International License (http:// creativecommons.org/licenses/by/4.0/), which permits unrestricted use, distribution, and reproduction in any medium, provided you give appropriate credit to the original author(s) and the source, provide a link to the Creative Commons license, and indicate if changes were made.

\section{REFERENCES}

Anderson, M.J. 2001. A new method for non-parametric multivariate analysis of variance. Austral Ecology 26: 32-46.

Ansara-Ross, T.M., M.J. Ross, and V. Wepener. 2013. The use of feathers in monitoring bioaccumulation of metals and metalloids in the South African endangered African grass-owl (Tyto capensis). Ecotoxicology 22: 1072-1083.

Battaglia, A., S. Ghidini, G. Campanini, and R. Spaggiari. 2005. Heavy metal contamination in little owl (Athene noctua) and common buzzard (Buteo buteo) from northern Italy. Ecotoxicology and Environmental Safety 60: 61-66.

Bedrosian, B., D. Craighead, and R. Crandall. 2012. Lead exposure in bald eagles from big game hunting, the continental implications and successful mitigation efforts. PLOS ONE 7: e51978.

Binkowski, L.J., R.M. Stawarz, and M. Zakrzewski. 2013. Concentrations of cadmium, copper and zinc in tissues of mallard and coot from southern Poland. Journal of Environmental Science and Health, Part B 48: 410-415.

Branco, V., J. Canário, J. Lu, A. Holmgren, and C. Carvalho. 2012. Mercury and selenium interaction in vivo: Effects on thioredoxin reductase and glutathione peroxidase. Free Radical Biology \& Medicine 52: 781-793.

Brzoska, M.M., and J. Moniuszko-Jakoniuk. 2001. Interactions between cadmium and zinc in the organism. Food and Chemical Toxicology 39: 967-980.

Bujoczek, M., and M. Ciach. 2009. Seasonal changes in the avian diet of breeding sparrowhawks Accipiter nisus: How to fulfill the offspring's food demands. Zoological Studies 48: 215-222.

Burgat, V. 1990. Un micropollutant: le cadmium. Bulletin Mensuel de l'Office National de la Chasse 146: 40-42.

Carneiro, M., B. Colaco, R. Brandão, C. Ferreira, N. Santos, V. Soeiro, L. Colaco, M.J. Pires, et al. 2014. Biomonitoring of heavy metals $(\mathrm{Cd}, \mathrm{Hg}$, and $\mathrm{Pb})$ and metalloid (As) with the Portuguese common buzzard (Buteo buteo). Environmental Monitoring and Assessment 186: 7011-7021.

Castro, I., J.R. Aboal, J.A. Fernández, and A. Carballeira. 2011. Use of raptors for biomonitoring of heavy metals: Gender, age and tissue selection. Bulletin of Environmental Contamination and Toxicology 86: 347-351.

Chmielnicka, J., T. Halatek, and U. Jedlińska. 1989. Correlation of cadmium-induced nephropathy and the metabolism of endogenous copper and zinc in rats. Ecotoxicology and Environmental Safety 18: 268-276.

Chodkiewicz, T., G. Neubauer, P. Chylarecki, A. Sikora, Z. Cenian, M. Ostasiewicz, P. Wylegała, Ł. Ławicki, et al. 2013. Monitoring of Polish birds in 2012-2013. Biuletyn Monitoringu Przyrody 11: 1-72 (in Polish).

Chodkiewicz, T., L. Kuczyński, A. Sikora, P. Chylarecki, G. Neubauer, Ł. Ławicki, and T. Stawarczyk. 2015. Population estimates of breeding birds in Poland in 2008-2012. Ornis Polonica 56: 149-189 (in Polish).

Clarke, K.R. 1993. Non-parametric multivariate analysis of changes in community structure. Australian Journal of Ecology 18: $117-143$

Conover, M.R., and J.L. Vest. 2009. Concentrations of selenium and mercury in eared grebes (Podiceps nigricollis) from Utah's Great Salt Lake, USA. Environmental Toxicology and Chemistry 28: 1319-1323.

Cramp, S.C., and K.E.C. Simmons. 1980. The birds of the western Palearctic, vol. 2. Oxford: Oxford University Press.

Deinet, S., C. Ieronymidou, L. McRae, I.J. Burfield, R.P. Foppen, B. Collen, and M. Böhm. 2013. Wildlife comeback in Europe: The recovery of selected mammal and bird species. Final report to 
Rewilding Europe by ZSL. London: Bird Life International, European Bird Census Council.

Esselink, H., F.M. van der Geld, L.P. Jager, G.A. Posthuma-Trumpie, P.E.F. Zoun, and A.J. Baars. 1995. Biomonitoring heavy metals using the barn owl (Tyto alba guttata): Source of variation especially relating to body condition. Archives of Environmental Contamination and Toxicology 28: 471-486.

European Environment Agency. 2012. European Environment Agency. http://land.copernicus.eu/pan-european/corine-landcover/clc-2012. Retrieved 1 Oct 2017.

Falandysz, J., H. Ichihashi, K. Szymczak, S. Yamasaki, and T. Mizera. 2001. Metallic elements and metal poisoning among white-tailed sea eagles from the Baltic Sea. Marine Pollution Bulletin 42: 1190-1193.

Farina, L.L., D.J. Heard, D.M. LeBlanc, J.O. Hall, G. Stevens, J.F. Wellehan, and C.J. Detrisac. 2005. Iron storage disease in captive Egyptian fruit bats (Rousettus aegyptiacus): Relationship of blood iron parameters to hepatic iron concentrations and hepatic histopathology. Journal of Zoo and Wildlife Medicine 36: $212-221$.

Forsman, D. 1999. The raptors of Europe and the Middle East: A handbook of field identification. London: T. \& A.D. Poyser.

Franson, J.C. 1996. Interpretation of tissue lead residues in birds other than waterfowl. In Environmental contaminants in wildlife: Interpreting tissue concentrations, ed. W.N. Beyer, G.H. Heinz, and A.W. Redmon-Norwood, 265-279. Boca Raton: CRC Press, Lewis Publishers.

Franson, J.C., L. Sileo, O.H. Pattee, and J.F. Moore. 1983. Effects of chronic dietary lead in American kestrels (Falco sparverius). Journal of Wildlife Diseases 19: 110-113.

Furness, R.W. 1996. Cadmium in birds. In Environmental contaminants in wildlife, ed. W.N. Beyer, G.H. Heinz, and A.W. Redmon-Norwood, 389-404. Boca Raton: CRC Press.

Garcia-Fernandez, A.J., J.A. Sanchez-Garcia, M. Gomez-Zapata, and A. Luna. 1996. Distribution of cadmium in blood and tissues of wild birds. Archives of Environmental Contamination and Toxicology 30: 252-258.

Gomez-Ramírez, P., R.F. Shore, N.W. Van Den Brink, B. Van Hattum, J.O. Bustnes, G. Duke, C. Fritsch, A.J. Garcia-Fernadez, et al. 2014. An overview of existing raptor contaminant monitoring activities in Europe. Environment International 67: $12-21$.

Guitart, R., J. To-Figueras, R. Mateo, A. Bertolero, S. Cerradelo, and A. Martiinez-Vilalta. 1994. Lead poisoning in waterfowl from the Ebro Delta, Spain: Calculations of lead exposure thresholds for mallards. Archives of Environmental Contamination and Toxicology 27: 289-293.

Hailer, F., B. Helander, A.O. Folkestad, S.A. Ganusevich, S. Garstad, P. Hauff, C. Koren, V.B. Masterov, et al. 2007. Phylogeography of the white tailed eagle, a generalist with large dispersal capacity. Journal of Biogeography 34: 1193-1206.

Hammer, Ø., D.A.T. Harper, and P.D. Ryan. 2001. PAST: Paleontological statistics software package for education and data analysis. Palaeontologia Electronica 4: 1-9.

Hartzell, S.E. 2014. land use impacts on selenium accumulation in vegetation and soil. BSc Thesis. Williamsburg: College of William and Mary, Virginia.

Helander, B., B. Ekman, J.-E. Hagerroth, P.-A. Hagerroth, and J. Israelsson. 1989. Age-specific field characteristics of the whitetailed sea eagle, Haliaeetus albicilla. Var Vagelvarld 48: 319-334.

Helander, B., J. Axelsson, H. Borg, K. Holm, and A. Bignert. 2009. Ingestion of lead from ammunition and lead concentrations in white-tailed sea eagles (Haliaeetus albicilla) in Sweden. Sciences of Total Environment 407: 5555-5563.
Hinkle, D.E., W. Wiersma, and S.G. Jurs. 2003. Applied statistics for the behavioral sciences. Boston: Houghton Mifflin Press.

Hlawiczka, S., and M. Cenowski. 2013. Systematics of anthropogenic processes generating solid wastes containing mercury. Inżynieria i Ochrona Środowiska 16: 125-140 (in Polish).

Honda, K., J.E. Marcovecchio, S. Kan, R. Tatsukawa, and H. Ogi. 1990. Metal concentrations in pelagic seabirds from the North Pacific Ocean. Archives of Environmental Contamination and Toxicology 19: 704-711.

Horai, S., I. Watanabe, H. Takada, Y. Iwamizu, T. Hayashi, S. Tanabe, and K. Kuno. 2007. Trace element accumulations in 13 avian species collected from the Kanto area, Japan. Sciences of Total Environment 373: 512-525.

Jager, L.P., F.V.J. Rijnierse, H. Esselink, and A.J. Baars. 1996. Biomonitoring with the buzzard Buteo buteo in the Netherlands: Heavy metals and sources of variation. Journal of Ornithology 137: 295-318.

Kalisińska, E., W. Salicki, and A. Jackowski. 2006. Six trace metals in white-tailed eagle from northwestern Poland. Polish Journal of Environmental Studies 15: 727-737.

Kalisinska, E., P. Lisowski, D. Czernomysy-Furowicz, and K.M. Kavetska. 2008a. Serratospiculiasis, mycosis, and hemosiderosis in wild peregrine falcon from Poland. Case report. Bulletin of the Veterinary Institute in Pulawy 52: 75-79.

Kalisinska, E., I. Rzad, J. Sitko, K.M. Kavetska, K. Królaczyk, and H. Budis. 2008b. Digenea of Haliaeetus albicilla (Linnaeus, 1758) and Pandion haliaetus (Linnaeus, 1758) from middle and north western Poland. Wiadomosci Parazytologiczne 54: 349-351 (in Polish).

Kalisinska, E., N. Lanocha, H. Budis, A. Wilk, K.M. Kavetska, and K. Krolaczyk. 2009. Essential trace elements in liver and kidneys of the common buzzard Buteo buteo and the Kestrel Falco tinnunculus. In Birds-environments-threats-conservation: Selected issues in avian ecology, ed. J. Wiacek, M. Polak, M. Kucharczyk, G. Grzywaczewski, and L. Jerzak, 215-226. Lublin: LTO (in Polish).

Kalisinska, E., D.I. Kosik-Bogacka, P. Lisowski, N. Lanocha, and A. Jackowski. 2013. Mercury in the body of the most commonly occurring European game duck, the mallard (Anas platyrhynchos L. 1758). Archives of Environmental Contamination and Toxicology 64: 583-593.

Kalisinska, E., J. Gorecki, A. Okonska, B. Pilarczyk, A. TomzaMarciniak, H. Budis, N. Lanocha, D. Kosik-Bogacka, et al. 2014a. Mercury and selenium in the muscle of piscivorous common mergansers (Mergus merganser) from a seleniumdeficient European country. Ecotoxicology and Environmental Safety 101: 107-115.

Kalisinska, E., J. Gorecki, A. Okonska, B. Pilarczyk, A. TomzaMarciniak, H. Budis, N. Lanocha, D. Kosik-Bogacka, et al. 2014b. Hepatic and nephric mercury and selenium concentrations in common mergansers, Mergus merganser, from Baltic region, Europe. Environmental Toxicology and Chemistry 33: 421-430.

Kalisińska, E., J. Gorecki, N. Lanocha, A. Okonska, J.B. Melgarejo, H. Budis, I. Rzad, and J. Golas. 2014c. Total and methylmercury in soft tissues of white-tailed eagle (Haliaeetus albicilla) and osprey (Pandion haliaetus) collected in Poland. Ambio 43: 858-870.

Kalisinska, E., N. Lanocha-Arendarczyk, D. Kosik-Bogacka, H. Budis, B. Pilarczyk, A. Tomza-Marciniak, J. Podlasinska, L. Cieslik, et al. 2017. Muscle mercury and selenium in fishes and semiaquatic mammals from a selenium-deficient area. Ecotoxicology and Environmental Safety 136: 24-30.

Kenntner, N., F. Tataruch, and O. Krone. 2001. Heavy metals in soft tissue of white-tailed eagles found dead or moribund in Germany 
and Austria from 1993 to 2000. Environmental Toxicology and Chemistry 20: 1831-1837.

Kim, J., and J.M. Oh. 2012. Metal levels in livers of waterfowl from Korea. Ecotoxicology and Environmental Safety 78: 162-169.

Kim, J., and J.M. Oh. 2015. Assessment of trace element concentrations in birds of prey in Korea. Archives of Environmental Contamination and Toxicology 71: 26-34.

Kim, E.Y., K. Saeki, S. Tanabe, H. Tanaka, and R. Tatsukwa. 1996. Specific accumulation of mercury and selenium in seabirds. Environmental Pollution 94: 261-265.

Kim, J., H. Lee, and T.H. Koo. 2008. Heavy-metal concentrations in three owl species from Korea. Ecotoxicology 17: 21-28.

Kim, J., J.R. Shin, and T.H. Koo. 2009. Heavy metal distribution in some wild birds from Korea. Archives of Environmental Contamination and Toxicology 56: 317-324.

Kitowski, I., A. Sujak, D. Wiącek, W. Strobel, and M. Rymarz. 2014. Trace element residues in eggshells of Grey Heron (Ardea cinerea) from colonies of East Poland. North-West Journal of Zoology 10: 346-354.

Knott, J., J. Gilbert, D.G. Hoccom, and R.E. Green. 2010. Implications for wildlife and humans of dietary exposure to lead from fragments of lead rifle bullets in deer shot in the UK. Science of the Total Environment 409: 95-99.

Komosa, A., I. Kitowski, and Z. Komosa. 2012. Essential trace (Zn, $\mathrm{Cu}, \mathrm{Mn})$ and toxic $(\mathrm{Cd}, \mathrm{Pb}, \mathrm{Cr})$ elements in the liver of birds from Eastern Poland. Acta Veterinaria (Beograd) 62: 579-589.

Kondracki, J. 2002. Geografia regionalna Polski. Warsaw: PWN, p. 635 (in Polish).

Kramer, J.L., and P.T. Redig. 1997. Sixteen years of lead poisoning in eagles, 1980-1995: An epizootiologic view. Journal of Raptor Research 31: 327-332.

Krone, O., F. Wille, N. Kenntner, D. Boertmann, and F. Tataruch. 2004. Mortality factors, environmental contaminants, and parasites of white-tailed sea eagles from Greenland. Avian Diseases 48: $417-424$

Krone, O., T. Stjernberg, N. Kenntner, F. Tataruch, J. Koivusaari, and I. Nuuja. 2006. Mortality factors, helminth burden, and contaminant residues in white-tailed sea eagles (Haliaeetus albicilla) from Finland. Ambio 35: 98-104.

Krone, O., J. Waldenström, G. Valkiunas, O. Lessow, K. Müller, T.A. Iezhova, and S. Bensch. 2008. Haemosporidian blood parasites in European birds of prey and owls. Journal of Parasitology 94: $709-715$

Krüger, O. 2005. The evolution of reversed sexual size dimorphism in hawks, falcons and owls: A comparative study. Evolutionary Ecology 19: 467-486.

Langguth, T., A.C. Honnen, F. Hailer, T. Mizera, S. Skoric, U. Väli, and F.E. Zachos. 2013. Genetic structure and phylogeography of a European flagship species, the white-tailed sea eagle Haliaeetus albicilla. Journal of Avian Biology 44: 263-271.

Lewis, L.A., R.J. Poppenga, W.R. Davidson, J.R. Fischer, and K.A. Morgan. 2001. Lead toxicosis and trace element levels in wild birds and mammals at a firearms training facility. Archives of Environmental Contamination and Toxicology 41: 208-214.

Lopez-Alonso, M., J.L. Benedito, M. Miranda, C. Castillo, J. Hernandez, and R.F. Shore. 2002. Interactions between toxic and essential trace metals in cattle from a region with low levels of pollution. Archives of Environmental Contamination and Toxicology 42: 165-172.

Łuczyńska, J. 2005. The influence of weight and length on the mercury content in the muscle tissue of fish from four lakes in the Olsztyn Lake District (Poland). Archives of Polish Fishery 13: 51-61.

Martin, P.A., D. Campbell, K. Hughes, and T. McDaniel. 2008. Lead in the tissues of terrestrial raptors in southern Ontario, Canada, 1995-2001. Sciences of Total Environment 391: 96-103.
Mateo, R. 2009. Lead poisoning in wild birds in Europe and the regulations adopted by different countries. Ingestion of lead from spent ammunition: Implications for wildlife and humans. In Ingestion of lead from spent ammunition: Implications for wildlife and humans, ed. M. Fuller, M. Pokras, and W.G. Hunt, 71-98. Boise: The Peregrine Fund.

Miller, M.J., M. Restania, R. Harmata, G. Bortolotti, and M.E. Wayland. 1998. A comparison of blood lead levels in bald eagles from two regions on the Great Plains of North America. Journal of Wildlife Disease 34: 704-714.

Mizera, T. 2004. White tailed eagle Haliaeetus albicilla (L., 1758). In Birds. Manual of habitats and species conservation-Natura 2000, ed. M. Gromadzki. Warsaw: Ministry of the Environment (in Polish).

Mortvedt, J.J. 1995. Heavy metal contaminants in inorganic and organic fertilizers. Fertilizer Research 43: 55-61.

Nadjafzadeh, M., H. Hofer, and O. Krone. 2013. The link between feeding ecology and lead poisoning in white-tailed eagles. Journal of Wildlife Management 77: 48-57.

Nadjafzadeh, M., H. Hofer, and O. Krone. 2016a. Sit-and-wait for large prey: Foraging strategy and prey choice of white-tailed eagles. Journal of Ornithology 157: 165-178.

Nadjafzadeh, M., C.C. Voigt, and O. Krone. 2016b. Spatial, seasonal and individual variation in the diet of white-tailed eagles Haliaeetus albicilla assessed using stable isotope ratios. Ibis 158: $1-15$.

Nam, D.H., and D.P. Lee. 2006. Reproductive effects of heavy metal accumulation on breeding feral pigeons (Columba livia). Sciences of Total Environment 366: 682-687.

Nam, D.H., Y.T. Anan, S. Ikemoto, and S. Tanabe. 2005a. Multielemental accumulation and its intracellular distribution in tissues of some aquatic birds. Marine Pollution Bulletin 50: $1347-1362$.

Nam, D.H., Y. Anan, T. Ikemoto, Y. Okaze, E.Y. Kim, A. Subramanian, K. Saeki, and S. Tanabe. 2005b. Specific accumulation of 20 trace elements in great cormorants (Phalacrocorax carbo) from Japan. Environmental Pollution 134: 503-514.

Nam, D., J. Rutkiewicz, and N. Basu. 2012. Multiple metals exposure and neurotoxic risk in bald eagles (Haliaeetus leucocephalus) from two Great Lakes states. Environmental Toxicology and Chemistry 31: 623-631.

Netto, A.S., M.A. Zanetti, L.B. Correa, G.R. Del Claro, M.S.V. Salles, and F.G. Vilela. 2014. Effects of dietary selenium, sulphur and copper levels on selenium concentration in the serum and liver of lamb. Asian-Australasian Journal of Animal Sciences 27: 1082-1087.

Newton, I. 1979. Population ecology of raptors. Vermillion: Buteo Books.

Nimni, M.E., B. Han, and F. Cordoba. 2007. Are we getting enough sulfur in our diet? Nutrition and Metabolism 4: 24.

Nowakowska, E., B. Pilarczyk, R. Pilarczyk, A. Tomza-Marciniak, and M. Bąkowska. 2014. Selenium content in selected organs of roe deer (Capreolus capreolus) as a criterion to evaluate environmental abundance of this element in Poland. International Journal of Environmental Research 8: 569-576.

Ochiai, K., K. Jin, C. Itakura, M. Goryo, K. Yamashita, N. Mizuno, T. Fujinaga, and T. Tsuzuki. 1992. Pathological study of lead poisoning in whooper swans (Cygnus cygnus) in Japan. Avian Diseases 36: 313-323.

Ohlendorf, H.M. 1989. Bioaccumulation and effects of selenium in wildlife. In Selenium in agriculture and the environment, ed. L.W. Jacobs, 133-177. Madison: Soil Science Society of America.

Otero, N., L. Vitoria, A. Soler, and A. Canals. 2005. Fertiliser characterisation: Major, trace and rare earth elements. Applied Geochemistry 20: 1473-1488. 
Pacyna, E.G., J.M. Pacyna, J. Fudala, E. Strzelecka-Jastrzab, S. Hlawiczka, and D. Panasiuk. 2006. Mercury emissions to the atmosphere from anthropogenic sources in Europe in 2000 and their scenarios until 2020. Sciences of Total Environment 370: 147-156.

Pain, D.J., J. Sears, and I. Newton. 1995. Lead concentrations in birds of prey in Britain. Environmental Pollution 87: 173-180.

Perrins, C.M., G. Cousquer, and J. Waine. 2003. A survey of blood lead levels in mute swans Cygnus olor. Avian Pathology 32: 205-212.

Petrie, S.A., S.S. Badzinski, and K.G. Drouillard. 2007. Contaminants in lesser and greater scaup staging on the lower Great Lakes. Archives of Environmental Contamination and Toxicology 52: 580-589.

Poulin, R. 1998. Evolutionary ecology of parasites. London: Chapman \& Hall.

Radwan, S., W. Kowalik, and R. Kornijow. 1990. Accumulation of heavy metals in a lake ecosystem. Sciences of Total Environment 96: 121-129.

Scheuhammer, A.M. 1987. The chronic toxicity of aluminium, cadmium, mercury, and lead in birds-a review. Environmental Pollution 46: 263-295.

Scheuhammer, A.M., N. Basu, N.M. Burgess, J.E. Elliott, G.D. Campbell, M. Wayland, L. Champoux, and J. Rodrigue. 2008. Relationships among mercury, selenium, and neurochemical parameters in common loons (Gavia immer) and bald eagles (Haliaeetus leucocephalus). Ecotoxicology 17: 93-101.

Schummer, M.L., S.A. Petrie, S.S. Badzinski, M. Deming, C. YuWie, and N. Belzile. 2011. Elemental contaminants in livers of mute swans on Lakes Erie and St. Clair. Archives of Environmental Contamination and Toxicology 61: 677-687.

Shore, R.F., M.G. Pereira, L.A. Walker, and D.R. Thompson. 2011. Mercury in nonmarine birds and mammals. In Environmental contaminants in biota, ed. W.N. Beyer, and J.P. Meador, 609-642. Boca Raton: CRC Press.

Skorbiłowicz, E. 2014. Assessment of heavy metals contents in bottom sediments of Bug river. Journal of Ecological Engineering 15: 82-89.

Slagsvold, A., and G. Sonerud. 2007. Prey size and ingestion rate in raptors: Importance for sex roles and reversed sexual size dimorphism. Journal of Avian Biology 38: 650-661.

Sokal, R.R., and F.J. Rohlf. 1981. Biometry: The principles and practice of statistics in biological research. New York: W.H. Freeman.

StatSoft, Inc. 2014. StatSoft, Inc., Francisco Partners \& Elliot Management statistical software, edition 2014. ed.

Stauber, E., N. Finch, P.A. Talcott, and J.M. Gay. 2010. Lead poisoning of bald (Haliaeetus leucocephalus) and golden (Aquila chrysaetos) eagles in the US inland Pacific Northwest regionAn 18-year retrospective study: 1991-2008. Journal of Avian Medicine and Surgery 24: 279-287.

Stout, J.H., and K.A. Trust. 2002. Elemental and organochlorine residues in bald eagles from Adak Island, Alaska. Journal of Wildlife Disease 38: 511-517.

Sunde, P., M.S. Bølstad, and J.D. Møller. 2003. Reversed sexual dimorphism in tawny owls, Strix aluco, correlates with duty division in breeding effort. Oikos 101: 265-278.

Szul, T. 2011. Final energy consumption in heating in rural areas of the Lublin province. Journal of Research and Applications in Agricultural Engineering 56: 139-141.

Tamas, M.J., and E. Martinoia. 2006. Molecular biology of metal homeostasis and detoxification. Berlin, Heidelberg, New York: Springer. Springer.

Temeles, E.J. 1986. Reversed sexual dimorphism: Effect on resource defense and foraging behaviours of non-breeding northern harriers. Auk 103: 70-78.
Toohey, J.I. 2014. Sulfur amino acids in diet-induced fatty liver: A new perspective based on recent findings. Molecules 19: 8334-8349.

van Rijn, S.V., M. Zijlstra, and R.G. Bijlsma. 2010. Wintering whitetailed eagles Haliaeetus albicilla in The Netherlands: Aspects of habitat scale and quality. Ardea 98: 373-382.

Wahba, Z.Z., T.P. Coogan, S.W. Rhodes, and M.P. Waalkes. 1993. Protective effects of selenium on cadmium toxicity in rats: Role of altered toxicokinetics and metallothionein. Journal of Toxicology and Environmental Health, Part A 38: 171-182.

Wayland, M., and A.M. Scheuhammer. 2011. Cadmium in birds. In Environmental contaminants in biota: Interpreting tissue concentrations, ed. W.N. Beyer, and J.P. Meador, 644-667. Boca Raton: CRC Press.

Wayland, M., E. Neugebauer, and T. Bollinger. 1999. Concentrations of lead in liver, kidney, and bone of Bald and Golden eagles. Archives of Environmental Contamination and Toxicology 37: 267-272.

Wayland, M., L.K. Wilson, J.E. Elliott, M.J.R. Miller, T. Bollinger, M.K. Mcadie, K. Langerier, J. Keating, et al. 2003. Mortality, morbidity, and lead poisoning of eagles in western Canada, 1986-98. Journal of Raptor Research 37: 8-18.

Weech, S.A., L.K. Wilson, K.M. Langelier, and J.E. Elliott. 2003. Mercury residues in livers of bald eagles (Haliaeetus leucocephalus) found dead or dying in British Columbia, Canada (1987-1994). Archives of Environmental Contamination and Toxicology 45: 562-569.

Wiener, J.G., D.P. Krabbenhoft, G.H. Heinz, and A.M. Scheuhammer. 2003. Ecotoxicology of mercury. In Handbook of ecotoxicology, ed. D.J. Hoffman, B.A. Rattner, G.A. Burton, and J. Cairns, 409-463. Boca Raton, London, New York, Washington: CRC Press.

Wolska, L., J. Namiesnik, M. Michalska, and M. Bartoszewicz. 2008. Preliminary study on toxicity of aquatic ecosystems in Bug River Basin. Polish Journal of Environmental Studies 17: 811-816.

Zajusz-Zubek, E., and J. Konieczyński. 2014. Coal cleaning versus the reduction of mercury and other trace elements emissions from coal combustion processes. Archive of Environmental Protection 40: 115-127.

Zawadzka, D. 1999. Feeding habits of the black kite Milvus migrans, red kite Milvus milvus, white-tailed eagle Haliaeetus albicilla and lesser spotted eagle Aquila pomarina in Wigry National Park (NE Poland). Acta Ornithologica 34: 65-75.

Zawadzka, D., J. Zawadzki, and W. Sudnik. 2006. Population development, habitat requirements and ecology of the whitetailed Eagle Haliaeetus albicilla in the Augustów Forest. Notatki Ornitologiczne 47: 217-229 (in Polish).

\section{AUTHOR BIOGRAPHIES}

Ignacy Kitowski $(\varangle)$ is a Senior Lecturer at State School of Higher Education in Chełm, Poland. He is currently involved in cooperative projects studying the origin of pollutants accumulated in the internal organs of vertebrates. His main research topic includes the processes of accumulation of radionuclides and heavy metals in key organs of birds. His research interests also incorporate bird strikes and seed dispersal by birds.

Address: State School of Higher Education in Chełm, Pocztowa 54, 22-100 Chełm, Poland.

e-mail: ignacyk@autograf.pl

Dariusz Jakubas is an Associate Professor in the Department of Vertebrate Ecology and Zoology at the University of Gdańsk. His research interests include breeding and foraging ecology of waterbirds, influence of climate change on organisms, ecophysiology, and avian migration. 
Address: Department of Vertebrate Ecology and Zoology, University of Gdańsk, Wita Stwosza 59, 80-308 Gdańsk, Poland.

e-mail: biodj@univ.gda.pl

Dariusz Wiącek is an Adjunct at the Institute of Agrophysics, Polish Academy of Sciences in Lublin, Poland. His current research interests include application of optical spectroscopy, gas and liquid chromatography and mass spectrometry in environmental protection, and multi-disciplinary approach to agricultural sustainability.

Address: Institute of Agrophysics, Polish Academy of Sciences, Doświadczalna 4, 20-290 Lublin, Poland.

e-mail: d.wiacek@ipan.lublin.pl
Agnieszka Sujak is an Assistant Professor and a head of Department of Biophysics at the Life Sciences University of Lublin, Poland. She is a biophysicist specialized in all kinds of spectroscopies. Her interests include agricultural engineering and environmental sciences as well as the interactions of different compounds with cell membranes on molecular level. She is currently involved in cooperative project studying environmental bioindication with use of different organisms, including birds. The aim of the project is to create practical tools for environmental quality management in the broad sense. Address: Department of Biophysics, University of Life Sciences in Lublin, Akademicka 13, 20-933 Lublin, Poland.

e-mail: agnieszka.sujak@up.lublin.pl 